\title{
Celestial Aspects of Hittite Religion, Part 2: Cosmic Symbolism at Yazılıkaya
}

\section{Eberhard Zangger}

\author{
President, Luwian Studies, Zurich, Switzerland \\ e.zangger@|uwianstudies.org
}

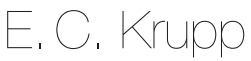

Director, Griffith Observatory, Los Angeles, USA

eckrupp@earthlink.net

Serkan Demirel

Department of Archaeology, Karadeniz Technical University, Trabzon, Turkey

serkandemirel@ktu.edu.tr

\section{Rita Gautschy}

Department of Ancient Civilizations, University of Basel, Switzerland rita.gautschy@unibas.ch

Abstract: Evidence of systematic astronomical observation and the impact of celestial knowledge on culture is plentiful in the Bronze Age societies of Egypt, Mesopotamia and Europe. An interest in astral phenomena is also reflected in Hittite documents, architecture and art. The rock-cut reliefs of 64 deities in the main chamber of Yazılıkaya, a Hittite rock sanctuary associated with Hattuša, the Hittite capital in central Anatolia, can be broken into groups marking days, synodic months and solar years. Here, we suggest that the sanctuary in its entirety represents a symbolic image of the cosmos, including its static levels (earth, sky, underworld) and the cyclical processes of renewal and rebirth (day/night, lunar phases, summer/winter). Static levels and celestial cyclicities are emphasised throughout the sanctuary - every single relief relates to this system. We interpret the central panel with the supreme deities, at the far north end of Chamber $A$, as a reference to the northern stars, the circumpolar realm and the world axis. Chamber $B$ seems to symbolise the netherworld.

Keywords: ancient calendars; archaeoastronomy; Bronze Age Anatolia; Hittite religion; lunisolar calendar; Yazılıkaya 


\section{The Rock Sanctuary of Yazılıkaya}

The history of supreme beings whose structure is celestial is of the utmost importance for an understanding of the religious history of humanity as a whole.

- Mircea Eliade, The Sacred and the Profane $(1957,121)$

While archaeoastronomical investigations have been successfully applied across the globe in recent decades (e.g. Ruggles 2015), throughout virtually the entire twentieth century the Anatolian subcontinent was not included in such studies and so became what might be regarded as a blank spot on the map of our knowledge of astral concerns in Bronze Age societies. In contrast, from about 2010 onwards there has been growing recognition of calendric and celestial elements in Hittite religion, too. An analysis of a statistically significant sample of Hittite sacred enclosures demonstrates that Hittite monuments adhered to well-defined patterns of astronomical and topographical orientations consistent with what we know of Hittite culture and religion (González-García and Belmonte 2014, 319-320; Belmonte and González-García 2015, 20). Winter solstice alignments seem overwhelmingly dominant in the orientation of more than 60 religious structures from the Hittite lands (González-García and Belmonte 2015, 1788). Similar architectural orientation has been recognised at Kuşaklı-Šarišša (Müller-Karpe 2013; 2015, $86 ; 2017,16-26)$. It is also well known that solar deities played a pre-eminent role in Hittite religion, a role deeply rooted in the Luwian milieu (Steitler 2017; Cammarosano 2018, 53-55).

The natural rock sanctuary of Yazllıkaya (Figure 1), which is considered to be one of the holiest places in the Hittite kingdom, has also recently been discussed by two of the present authors as potentially having a calendric function (Zangger and Gautschy 2019, 10). The reliefs in Chamber $A$ are arranged in groups that may keep track of and display days, synodic months and solar years. Intercalary months could have been introduced intermittently to synchronise the Moon with the solar year.

Earlier studies examined what seem to be other astronomical aspects of the site. Emilia Masson $(1989,107)$ suggested that once a year - during the winter solstice - a divine assembly took place in the adytum. E. C. Krupp argued that the festival's activities may have included a sacred marriage, a ceremony deeply rooted in the ancient Near East. That ritual reflected a renewal of "the matrimonial bond between the divine rulers of heaven and earth" and seasonally renewed the king's license to rule (Krupp 2005, 417; see also Krupp 1997a, 6; 1997b, 146; 2000, 44-47). Juan Antonio Belmonte (2000, 89) interpreted each of the 12 similar male gods marching in line in Chamber B (Reliefs 69-80) as an indicator of a synodic month, the time from one New Moon to the next, and the number 12 approximates the number of complete synodic months in a year. Another study has suggested that several of the deities depicted in Chamber A possess an astral character (González-García and Belmonte 2011, 5). Yet, despite the recent surge of stimulating insights into celestial concerns of Hittite religion, the total amount of available information is still so scarce that current and future research will inevitably have to rely on the methodology of comparative archaeology and use the vast amount of 
knowledge regarding archaeoastronomical aspects that has been accumulated over the past century and a half of research on Mesopotamia and Egypt. It is well established that the royal courts of these imperial kingdoms were in close contact and that there was cultural exchange; for instance, priests from Babylon were practising their religion and teaching their peers in Hattuša (Koch-Westenholz 1993, 233). Hence, it is legitimate to presume that the elite of the society was quite aware of religious practices abroad. This is evident from the correspondence between Queen Puduhepa, the wife of Hattušili III and mother of Tudhaliya IV, who was herself a Hurritic priestess, and Ramesses II (Otten 1975, 20).

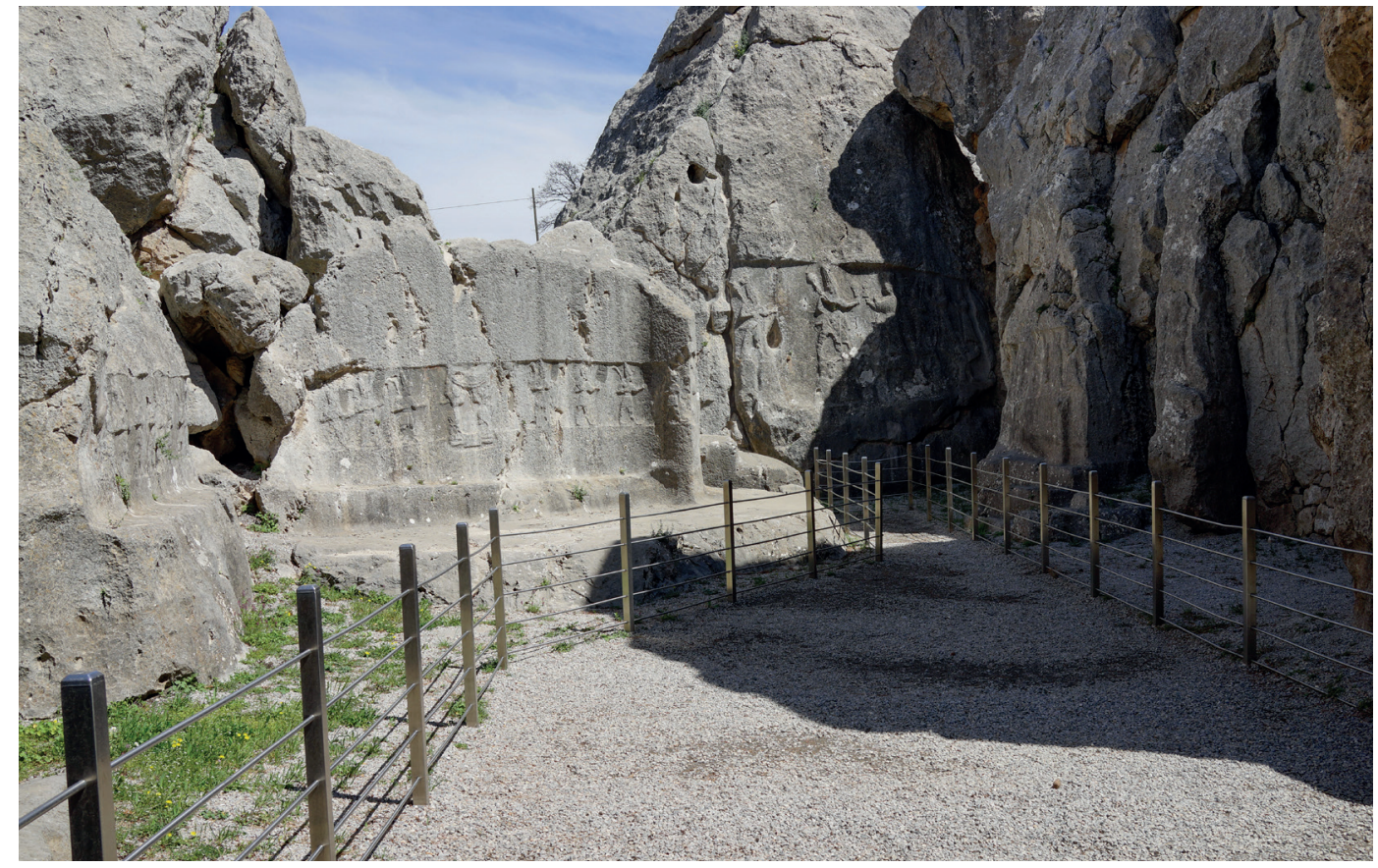

FIGURE 1. Chamber A of Yazllıkaya looking north towards the central panel (Reliefs 42-46) right ahead. The fence was built in 2008.

Any attempt to comprehend ancient civilisations often involves conjecture; Yazılıkaya, in its present form, dates to c. $1230 \mathrm{BC}$, which means more than three millennia have passed since the sanctuary took shape. To understand the part astronomy played in an ancient civilisation, we have to examine not only the observational function, the instrumental operation and the practical use of what may be astronomical material but also must explore its ideological function and its religious-mythological symbolism (Sims $2009,388 ; 2015,42)$. Here, we aim to review the number, character and placement of the Yazllıkaya figures to determine whether they may have fulfilled a symbolic function in 
addition to their use as a calendric display. Reconstructing the lost complexity of Hittite culture is facilitated by the fact that the Hittites left an enormous number of documents behind, many of which describe religious customs. In addition, Babylonian and Egyptian sources help shed light on the matter, for many astral elements of religion in Anatolia appear to have been borrowed from elsewhere (Beckman 2013a, 86; 2013b, 292; Rieken 2019, 160).

Cyclical patterns in the movement of the stars, the Sun, the Moon and the planets were observed and integrated into mythic tradition, even by hunter-gatherer communities (Fowler and Turner 1999, 422). Foraging peoples monitored the Milky Way and particularly obvious asterisms and constellations, including the Pleiades, Ursa Major (the seven stars of the Big Dipper) and Orion (the three Belt stars). They observed the monthly cycle of the Moon's growth, decline and renewal, as well as the solstices (Fowler and Turner 1999, 423). Our ancestors realised that the world is driven by cyclical renewal: day and night, light and darkness and the seasonal sequence of summer and winter. They saw how the fertility of nature is interlinked with seasonal celestial movements, how the Sun causes snow to melt and some flowers to open and how a river floods when a certain star or asterism becomes visible again in the night sky (Morley 2010, 16). They may have recognised the causal relationship between the Moon and the tides (Van der Waerden 1966, 33) and imagined a similar relationship between the Moon and the menstrual cycle (Eliade 1957, 101-102). While the Sun, for some, governed the fertility of the land, the Moon seemed bonded to human fertility. People integrated these beliefs into cyclical social relations connected with the annual round of subsistence and related ceremonies (Fowler and Turner 1999, 422). Events on earth were thought to recapitulate events in heaven and were believed to be based on the natural, lawful and ordered development of the universe (Winckler 1903,63). As a consequence, some peoples inferred that the cycle of life and death is governed by celestial power. In many belief systems, even time is cyclical (Morley 2010, 14).

Once a relationship between celestial cycles and terrestrial cycles is recognised, explanations are devised, and predictions are made. Near Eastern societies in the second millennium BC systematically studied and deliberately recorded astral phenomena to find in them a sign of what would happen in the future (Rochberg 2018, 26). In the ancient Near East and its immediate surroundings, including at Hattuša, celestial phenomena were observed, analysed, calculated and predicted by learned and specialised scribes (Huber and Sachs 1982; Rochberg 1992, 810-814; 2016, 19; Cohen 1993, 3).

Reflections about the sky are also found in ancient architecture, which from its very beginnings 12,000 years ago was closely associated with cult practices, as is evident in the monumental complexes and pillar shrines with theriomorphic figures in low relief unearthed at Göbekli Tepe (Schmidt 2006, 91). Neolithic dwellings in Stara Zagora, Bulgaria, dating to the sixth millennium $\mathrm{BC}$, already include structures oriented towards the solstices, most likely because the re-emerging Sun was already a metaphor for rebirth after death (Spence 2010, 170). The planners of the Egyptian pyramids must also have been skilled skywatchers (Magli and Belmonte 2009, 307), for the four sides of the Great Pyramid, built for the pharaoh Khufu (Fourth Dynasty; around 2560 BC) are aligned with 
the cardinal points to an accuracy of three arcminutes (Spence 2000, 321). What is more, the so-called "air shafts" within the Great Pyramid are symbolically oriented towards the Belt stars of Orion, circumpolar stars and perhaps Sirius (Krupp 1983, 102-105; Edwards 1993, 284-285; Magli and Belmonte 2009, 310-312; Brady 2015, 76). In addition, Egyptian Sun temples, erected in the middle of the third millennium BC, comprise a square court, a rectangular enclosing wall, a large obelisk and some storage rooms (Maier 2018, 82) and are cardinally oriented (Krupp 1988, 492-496). It has been observed that at the Egyptian city of Thebes in particular, "astronomy combines with religion, history and landscape to produce one of the most traditionally sacred spots on Earth" (Belmonte and González-García 2015, 16). A study of the orientation of 60 religious structures in the Hittite kingdom, however, provides even clearer evidence of solar alignments. The measurements were taken in the area of Hattuša; a few main peaks in the relevant normalised frequency histogram are correlated with the solstice Sun with a confidence higher than 99\% (Belmonte and González-García 2015, 19-20).

\section{External Evidence: Mesopotamian Cosmology}

Mesopotamian observations of celestial regularities likely had an impact on the cultures in the neighbouring regions. The Hittite court acquired knowledge of stargazing and divination from Babylon, where astronomical observation was driven by astrological and calendric objectives (Koch-Westenholz 1993; Beckman 2013b). Babylonian-based astrological prophesying included the interpretation of the movements of the Moon and the Sun (Weidner 1923; 1-8; Güterbock 1988; Koch-Westenholz 1993; Riemschneider 2004), which were believed to transmit messages from the gods. Since it was thought that celestial events precede what is going to happen on Earth, appropriate countermeasures could be taken to avert bad omens (Rochberg 2016, 244). The system for making predictions and the mechanisms for refuting fate were by no means uniform (Rochberg 2016, 256).

For the Hittites, however, the details are not clear. We neither know whether the Hittites made their own astrological observations, nor the extent to which they absorbed Babylonian celestial information. Manfred Hutter $(1997,75)$ argues more broadly that "it is not possible to explore Hittite religion without taking into consideration traditions from Syria and Mesopotamia" (see also Bittel 1941, 150-151). The Anatolians not only imported cuneiform writing but also the culture associated with it. This is evident from prayers (Beckman 2013b, 294-295). During the early period of the Hittite New Kingdom (c. 1450-1350 BC), Sumero-Akkadian prayers were imported from Mesopotamia and transformed into the Hittite "Prayers to the Sun God for Appeasing an Angry Personal God" (CTH 372-374; Rieken 2019, 150). This was acknowledged even in early Hittite research (Güterbock 1958, 241-242).

Hittite and Mesopotamian prayers both converge and diverge throughout Hittite history. In some instances, we still possess both the Sumero-Akkadian model text as well as the adaptation in the Hittite prayer (Rieken 2019, 151). Rieken $(2019,160)$ concludes that "not only the content, but also the shape of the individual prayers of Hittite kings and 
nobles has been deeply inspired by their Mesopotamian models". Other Mesopotamian imports included the deity lštar (Hurrian Šauška), whose popularity increased under the patronage of the above-mentioned Hattušili III and his Kizzuwatnean bride, Puduhepa (Collins 2007, 175). Nurturing Hurrian cults, however, merely revitalised a prevailing interest in Mesopotamian traditions (Collins forthcoming).

Overviews of the celestial components of Near Eastern cosmology of the third and second millennia BC have been provided by Hugo Winckler (1903; 1904; 1907), Alfred Jeremias (1909; 1929), Mircea Eliade (1954; 1957; 1978) and E. C. Krupp (1997b; 2000; 2005). According to these reviews, capital cities were not human inventions but instead part of the divine Creation. They replicated the structure of the cosmos and were viewed as the point of Creation, the eternal realm of the divine from which cosmic order emerged (Eliade 1954, 14-15). Like some monumental architecture, such as Egyptian temples (according to Greek and Roman sources - Maier 2018, 82), capital cities thus miniaturised the cosmos to a human scale. They were themselves seen as an epiphany, not just as the place where an epiphany would take place (Selz 2005, 34). As a centre of power, the capital city was often regarded as the centre of the world, and as sacred ground it was regarded as the place in closest contact with heaven (Eliade 1957, 39). Such capitals formed a knot tying the country to the sky and served as the locus where the spirits and divine rulers in heaven consorted with Earth (Winckler 1907, 104; Jeremias 1929, 110-111; Eliade 1957, 36-43; Krupp 2005, 426).

The principal beliefs behind Egyptian, Babylonian and Hittite temple architecture and recurring festivals show some parallels. For instance, in both ancient Babylonia and Hatti, the divinities "lived in" the temples as statues. They were bathed, dressed, fed and entertained with dances and music by the priests (KUB 25.24 obv. II 8-9; KUB 41.30 obv. III 2-9; see also Hazenbos 2003, 171; Eliade 1978, 140; Selz 2005, 109). Also, in Neo-Babylonian times, the Akitu, or New Year festival, was part of a detailed calendar of cultic activities providing an ideological link between the king, the people and the gods and intended to legitimise the king's rule and reinforce the collective identity (Steele 2012, 377). As part of this, it was "therefore important that all of the people [Babylonians] celebrated the festival [Akitu] at the same time" (Steele 2012, 377). This required deliberate determination of the first day of the new year and advance planning for festivals throughout the year.

\section{Internal Evidence: Hittite Cosmology}

The broad principles of traditional cosmologies appear to be present at Hattuša - as argued below, more so than previously thought. Hattuša was considered the city of the gods and temples (Schachner 2011, 172), and the elevated Yerkap structure at its southern end, much like the two chambers in Yazlıkaya, is aligned with the polar axis, which points to the hub of the sky and coincides with the world, or "cosmic", axis. The capital was believed to be the navel of the Earth, "where world order is nourished by the flow of celestial power" (Krupp 2005, 426). The storm god, as the supreme deity of the imperial pantheon since the beginning of Hittite history, was the keeper of this cosmic order, the protector of the kingship and legal relationships of the country, which the king administered for him (KUB 29.1 Vs.I 17-19, IBoT I 30; see also Haas 2002, 104; Gonnet 1987, 
183). Hittite mythological texts describe this process as it relates to Hattuša: first, the gods build a palace, while the king also builds a palace for himself (CTH 726; 2); then, the gods share the country and establish the royal power at Hattuša (CTH 725; 3). Finally, the king remembers how he received his power from the gods and declares how he will protect the palace and the royal kingship (CTH 414; Beckman 2013b, 290; Torri and Görke 2013, 293). Terrestrial rule is leveraged with a celestial mandate: "As the gods built their palace and kingdom, the king likewise built his palace and kingdom on Earth. Thus, the situation in heaven parallels that on earth" (Görke 2019, 164).

In Hatti - just as in Babylonia and Egypt - the temples served as ceremonial meeting places. Many temples were oriented towards the solstitial sunrises and sunsets (Belmonte and González-García 2015, 20) and replicated the principles known from Egypt (Van der Waerden 1974, 8-45). Solstices and the Full Moon may have marked completions of celestial cycles (Winckler 1907, 100-101, 129), and festivals may have marked the decisive points in the motion and behaviour of heavenly bodies. Anticipation of these points was the purpose of the calendar. The most important celestial events were the critical days of the Moon's cycle (New Moon, Full Moon) and the Sun's circuit through the year, with the four quarterly festivals at solstices and close to the equinoxes. The most important of these was chosen as New Year (Winckler 1907, 122).

Despite the complexity of Hittite religion, it is exceedingly well investigated. About $30 \%$ of the documents and fragments retrieved from the Hittite archives (around 10,000 items) are descriptions of religious festivals (Rieken 2019, 149), and most of the remainder deal with other religious practices and cult administration - in the form of descriptions of rituals, oracle reports, royal prayers, votive texts and cult inventories (Gilan 2019, 179). Hittite religion always integrated a variety of influences, including ancient Anatolian, Hattian, Luwian, Palaic, Hurrian, northern Syrian, Kizzuwatnean and Sumero-Akkadian elements, although the relationships between these varied in time and space (Gilan $2019,173)$. Astronomy is also evident in these records: for example, a god might signal to a person through an astronomical event, like a solar eclipse, lunar eclipse or meteor (Beckman 2013a, 92-93; 2013b, 290).

The religious activities described in the Hittite documents include numerous references to seasonal festivals (Süel 1985, 159-160), and some of these are related to architecture and city planning. Hattuša's major festivals were seasonal, in particular the Festival of Spring (EZEN4hamešhandaš) and the Festival of Autumn (EZEN4 zenandaš), and there was also a Festival of the Month (EZEN4ITU.KAM) and a Festival of the Year (EZEN4MU-ti). Some important festivals were celebrated on fixed dates in spring and autumn (EZEN4KI.LAM,

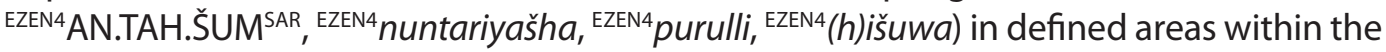
city and its immediate surroundings (Goetze 1951, 470; Güterbock 1997, 87-90).

Hittite cuneiform texts reveal hints that observations, calculations and predictions of celestial phenomena were made locally (KUB 55.21 rev. IV 1-3, KUB 9.22 II 46, KUB 9.15 II 16). The importance attributed to the correct timing of the festivals (KUB $13.4 \mathrm{obv} .57-68$ ), however, implies that celestial observations were essential, as they were for any society that organised goods, services and activities according to time. References to celestial concepts are encountered in cuneiform Luwian documents, such as the incantation rites 


\begin{tabular}{|c|c|}
\hline Phrase & Source \\
\hline "Sun gods" & KUB 9.31 Vs. ii 30; 35.45 Vs. ii 21; 25; 35.48 Vs. ii 19 \\
\hline "my Sun-like lord" & KUB 35.45 Vs. ii 18; 35.48 Vs. ii 11 \\
\hline "Sun goddess" & KUB 35.45 Vs. ii 26 \\
\hline "Sun goddess of the Earth" & KUB 35.45 Vs. ii 26; 35.48 Vs. ii 21 \\
\hline "Moon god" & KUB 35.102 Vs. ii 12; iii Rs iii 1 \\
\hline “Earth" & KUB 35.45 Vs. ii 26; 35.54 Vs. ii 41; 42; 43; Rs. iii 28; 35 \\
\hline "heaven and Earth" & $\begin{array}{l}\text { KUB } 7.53 \text { Vs. i 59; } 35.54 \text { Vs. ii 31; 41; 42; 44; iii 27; KBo } 22.254 \\
\text { Rs. } 11\end{array}$ \\
\hline "heaven and earthly things" & KUB 9.6 Vs. ii 14 \\
\hline "out of heaven" & KUB 7.53 Vs. i 59 \\
\hline "your day" & KUB 35.133 Vs. ii 27 \\
\hline "evil month" & KUB 32.9 Vs. $9 ; 28$ \\
\hline "year" & KUB 35.24 Vs.35; 32.9 Vs. 8; 27; 35.16 Vs. I 10 \\
\hline "long year(s)" & KUB 35.24 Vs. 35; 35.16 Vs. i 11-12; 35.43 Vs. ii 40 \\
\hline "evil year(s)" & KUB 32.9 Vs. $9 ; 28$ \\
\hline
\end{tabular}

TABLE 1. Celestial concepts frequently referenced in cuneiform Luwian documents.

of the Songs of Ištanuwa (Beckman 2013b, 294-295; Woudhuizen 2017). Table 1 lists the most frequent examples. The documents referenced in the table highlight the significance of celestial phenomena and hemerology in the Luwian/Hittite belief system.

\section{Keeping and Displaying the Calendar}

A calendar is a fundamental ordering principle of society. It facilitates social interaction and structures culture and worldview (Stern 2012, v). In antiquity, however, the formal calendar was almost exclusively dedicated to organising the religious year and determining the many festivals. Farmers, in contrast, always knew how to use rising stars as markers for the agricultural year; this is clearly attested in Mesopotamia, for example, in the Sumerian "Farmer's Instructions", which told the peasants to start the fieldwork "once the sky constellations are right" (quoted in Verderame 2015, 1837; see also Civil 1994).

Despite over 2000 astronomical documents and fragments from Niniveh, Uruk and Babylon (Brack-Bernsen 1997, 7), there is no explicit description of how the formal calendar was operated in any extant Mesopotamian cuneiform source (Stern 2012, 74). The same is true for Hittite documents. Even so, with the surviving texts it is still possible to reconstruct with high geographical and chronological resolution which fixed calendar was used when and where in different parts of the ancient Near East (Cohen 2015) 
including Hatti (Demirel 2017), since festivals were held to coincide with certain seasons and agricultural activities.

\subsection{External Evidence (Mesopotamia)}

The calendar employed in Mesopotamia from at least the late fourth millennium BC to the beginning of the first millennium AD was lunisolar (Steele 2012, 374; Gautschy 2020, 159). Sources from Mesopotamia and the Levant in the third and second millennia BC show that numerous calendars did exist initially and that intercalation was already practised from the third millennium BC (Stern 2012, 94). In the course of the second millennium BC, a standard sequence of months became dominant in Babylon, later spread to the whole of Mesopotamia and is particularly attested for Assyria (Cohen 1993, 302-303; Stern 2012, 71). Intercalations were then made at fairly regular intervals and were limited to months 6 and 12 (Stern 2012, 95). This propagation of a unified calendar reinforced administrative objectives and ideology.

The schematic calendar used administratively from the thirty-fourth century $B C$ onward was slightly different from the modern solar calendar. A "year" comprised 360 days, a number that facilitated computations for trade, debts, rents and leases and which provided fixed dates for the solstices and equinoxes in astronomical texts such as MUL.APIN, a Mesopotamian compendium of celestial information. Lunar months were standardised to 30 days (Steele 2012, 375; Rochberg 2018, 28; Gautschy 2020, 161), a number that symbolised the Moon god (Rochberg 2016, 195) and which worked well with the Sumerian mathematical system, which was based on the numbers 6 and 60 (Duncan 1998, 18). The product of those two factors, 360, is still used to divide circles and the dome of the sky.

A designated authority must proclaim the beginning of each new month and communicate that information to the larger community that shares that calendar and depends on it (Steele 2012, 373-374). In ancient Rome, the New Moon was announced by priests (Blum 2016, 34) - a tradition preserved in the word "calendar", derived from Latin caläre, which means "to proclaim".

\subsection{Internal Evidence (Hatti)}

Although we do not know who maintained the Hittite calendars, directive texts for the temple officials indicate that the holidays should be celebrated on the days specified in the holy calendar (KUB 13.4 obv. 60-61). Failing to do so would be an insult to the gods and require punishment (Süel 1985, 166). Such warnings, issued by the king and addressed to the temple priests, make it very likely that the priests were responsible for keeping the calendar. Precise orders were given by temple officials for celebrating the spring and autumn festivals at the right time (KUB 13.4 obv. 57-68; Süel 1985, 46, 48). The documents explicitly state that the festivals were to be organised on a regular basis (KBo 3.4 I 21-22, III 23-25) and that any negligence or deviation in time will be considered with disfavour by the gods (KBo 3.4 obv. I 16-18). 
At about the time of Muršili II, a reform moved the beginning of the year from around the autumnal equinox to around the vernal equinox (Hutter 1997, 82). The festivals then occurred from spring to autumn and celebrated events from sowing to harvest (Güterbock 1964, 63-73).

\section{Yazılıkaya's Western Wall in Chamber A: Symbols of Earth and Sky}

Yazılıkaya's open-air, natural rock setting was carefully selected as the site for the Hittite rock sanctuary (Haas 2011, 174); the chambers are well configured for restricted access and focused action. Its rocky pinnacles appear to mimic high mountains, and like high mountains they are points of contact between earth and the sky. In a way, the natural stone walls operate like a stage on which the gods can assemble, witness and perform, while the rock reliefs of the gods create a divine audience for ritual. Yazılıkaya is fundamentally a rock art site, and throughout the world, the presence of rock art sometimes indicates that a place was regarded as a source or focus of numinous power where mythic cosmic forces converge and the power of gods and spirits may be witnessed or accessed (see, for example, Krupp 2006, 360-361). Access to celestial power was provided at such places linking earth and sky, where astronomical events and calendric circumstances were acknowledged (Krupp 2015, 68).

The selection of a natural site so near the built landscape indicates that the place had special meaning and was likely recognised as a place of power. The deities depicted there all could have instead been incorporated into a constructed building elsewhere, but they were engraved on bedrock outcrops reminiscent of mountain summits. The festivals perpetuated there in accordance with celestial cycles effectively placed the ruler at the centre of the world and endorsed his authority and licence to rule through a public display of his alliance with cosmic order. The king assumed the role of a terrestrial officer of cosmic order; his actions were thus carried out in congruence with the gods and linked his franchise with the natural order of the world. This myth helped advertise and explain the origin and acquisition of power invested in the ruler. Yazılıkaya, then, is well designed for ceremonies which recapitulate and illustrate the beginning of time, the structure and rhythm of the universe and the power of cyclical renewal (Haas 2011, 264).

It has recently been argued that the processions of deities depicted in Chamber A were used to help keep the religious calendar synchronised with the seasons (Zangger and Gautschy 2019, 10; Zangger and Gautschy 2020). Figure 2 shows how the three panels with a supposed operational function could have been used to display an accurate lunisolar calendar. The first group of reliefs (1-12, counting right to left) indicates the synodic months ( $12 \times 29.53059$ days), while the second group (Reliefs 13-41) marks the days of the lunar month beginning with the first visibility of the lunar crescent at Relief 41 and ending with the New Moon at Relief 14 or 13. The preserved reliefs on the eastern wall (Reliefs 46a-63) - plus one piece found at Yekbas, today kept in the local museum and which would fit into one of the gaps - show the number of years in a Metonic cycle (19 years $\times 365.2425$ days in a solar year at that time). The Metonic cycle coordinated the monthly cycle of the Moon with the solar year. In the reliefs, the sequence proceeds from right to left for the first two panels (months and days) and from left to right for the 
third panel (years). In Figure 2, the system operates like a slide rule, but at Yazılıkaya, the panels were, of course, fixed. The current month, day and year could, however, have been indicated with movable markers. The illustration shows the date for 4th July, 1250 $\mathrm{BC}$, that year's summer solstice. This operation only demonstrates the technical use of the sanctuary as a calendric tool, or more likely, as a display, but its features may also incorporate some of the metaphorical meaning that had evolved over a long period in Sumer, Babylonia and Egypt (Collins 2007, 191-192).

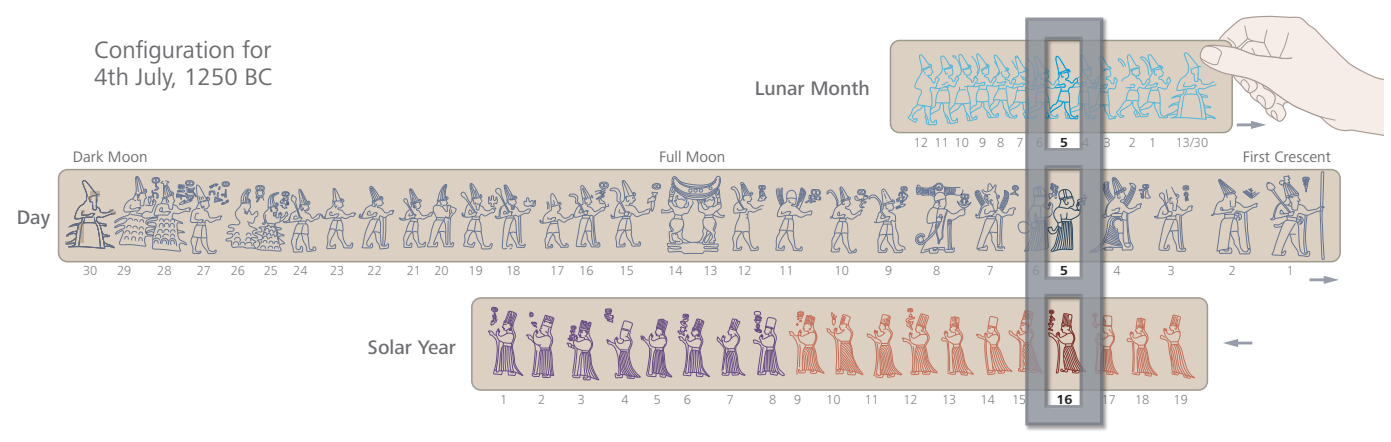

FIGURE 2. Schematic illustration showing how the three panels which displayed the date were used to maintain an accurate lunisolar calendar.

The principal deities at Yazılıkaya are the Hurrian storm god Teššub, his wife, the Hurrian goddess Hebat, and their son Šarruma. Although the links between them are controversial (Güterbock 1950, 90), these gods were associated with the storm god, the Sun goddess of Arinna, and the storm god of Zippalanda, respectively, in the Hittite pantheon (Beckman 2013b, 288). Their names were written with Luwian hieroglyphic signs but in the Hurrian language (Laroche 1969, 108; Güterbock 1975a, 186; Seeher 2011, 24), and that makes it clear that parts of the system were introduced from somewhere else (Bryce 2019, 241-242) and overlaid upon local Anatolian belief systems thousands of years older (Eliade 1978, 141). The Hittite state pantheon thus emerged from the most diverse local pantheons in Anatolian and Syrian cities. In accordance with the historical development of the Hittite state, the cults and deities of the previous Hatti-speaking population formed the oldest layer of the Hittite pantheon during the Old Hittite Kingdom (1600-1450 BC; Haas 2002, 103; Cammarosano 2018, 51), but the figures depicted in Yazılıkaya - their individual characters, their names and their symbols - are likely to be an amalgamation of ancient Hattian, Luwian, Hurrian and southern Mesopotamian traditions with maybe some elements picked up from Egypt. Today, the challenge lies in identifying and distinguishing these individual components.

Limited space precluded extended interpretation in our prior publication (Zangger and Gautschy 2019). We aim here to address three questions not considered earlier: 
- why do the figures used for counting the days (Reliefs 13-41) differ in character, while those for counting months (Reliefs 1-12) and years (Relief 46a-63) are virtually identical to each other?;

- what is the meaning (technically or metaphorically) of the central panel; and

- how can the symbolism of Chamber B be interpreted?

The 12 identical Reliefs 1-12 on the far left in Chamber A have long been suggested to represent the deities for the months and the passage of time through eternity (Cornelius 1973, 260, 345n34; see also Belmonte 2000, 89; González-García and Belmonte 2011, 5). According to Hittite cuneiform texts, the months were designated with consecutive numbers from 1 to 12. They did not have any other names (Demirel 2017, 22). An important study of traditional calendars in Anatolia based on interviews with local people has been conducted by Gürbüz Erginer $(1984,48)$. The interviewed people stated that if a month lasts 29 days the following month lasts 30 days, which constitutes the principle of a lunar calendar. Erginer interprets this as remnants of an Islamic calendar (Hicrî takvimin) that was used in Ottoman Anatolia. Most of the interviewed peasants did not know the names of the months used today. In general, they enumerated months from 1 to 12 in conversations among themselves.

Hittite priests attended monthly festivals at about the middle of each of the 12 months; that is, at the time of the Full Moon (KUB 42.100 IV 22-23; Del Monte 1987, 55). Thirteen monthly festivals with individual names are handed down for the weather god of Halab/Aleppo in Hattuša, of which the thirteenth may have served as a leap month (Haas 2011, 265).

The 30 relief figures that indicate the days of the month are, however, quite different in attitude, attribute and dress. Winged (celestial) deities correspond to the days of the waxing Moon, and mountain (terrestrial) gods with fountains flowing off from their robes are the waning days of the Moon. The figures descend in importance from right to left (Bryce 2019, 242) and exhibit "a meaningful sequence subject to a strict hierarchy" (Bittel $1970,97)$. We interpret the centre of the sequence, clearly emphasised with the depiction of the bull-men (Reliefs 28-29), as the day of the Full Moon. Good days of the month may correspond to the waxing Moon, and the days of waning Moon may be less propitious.

The original model for the Yazllıkaya lunar month procession may have associated the days with different distinctive deities, each a personification of a day of the lunar month. A similar panel with 14 gods depicting the 14 days of the waxing Moon is found in Egypt in the ceiling of the hypostyle hall of the Temple of Hathor at Dendera (Figure 3; Budge 1904, vol. 2, 321; Altmann-Wendling 2020a, 137). Although the ceiling relief is from the later Ptolemaic era, lists of days of the lunar month are well documented from earlier times, and most of those texts mention days from the waxing half of the month (Brugsch 1883, 310-311, 476-478; Altmann-Wendling 2020b, 123). The sequence at Dendera proceeds from left to right. The sequence at Yazılıkaya runs in the opposite direction, but the Full Moon night is highlighted in both instances. At Dendera, it is symbolised with a disk bearing the eye of Horus on a sickle-shaped support stand attended by the god 
Thoth (Krupp 1984, 292); at Yazilıkaya, it is marked by two bull-men, who carry a similarly sickle-shaped vessel which represents the Luwian hieroglyphic sign for "sky".
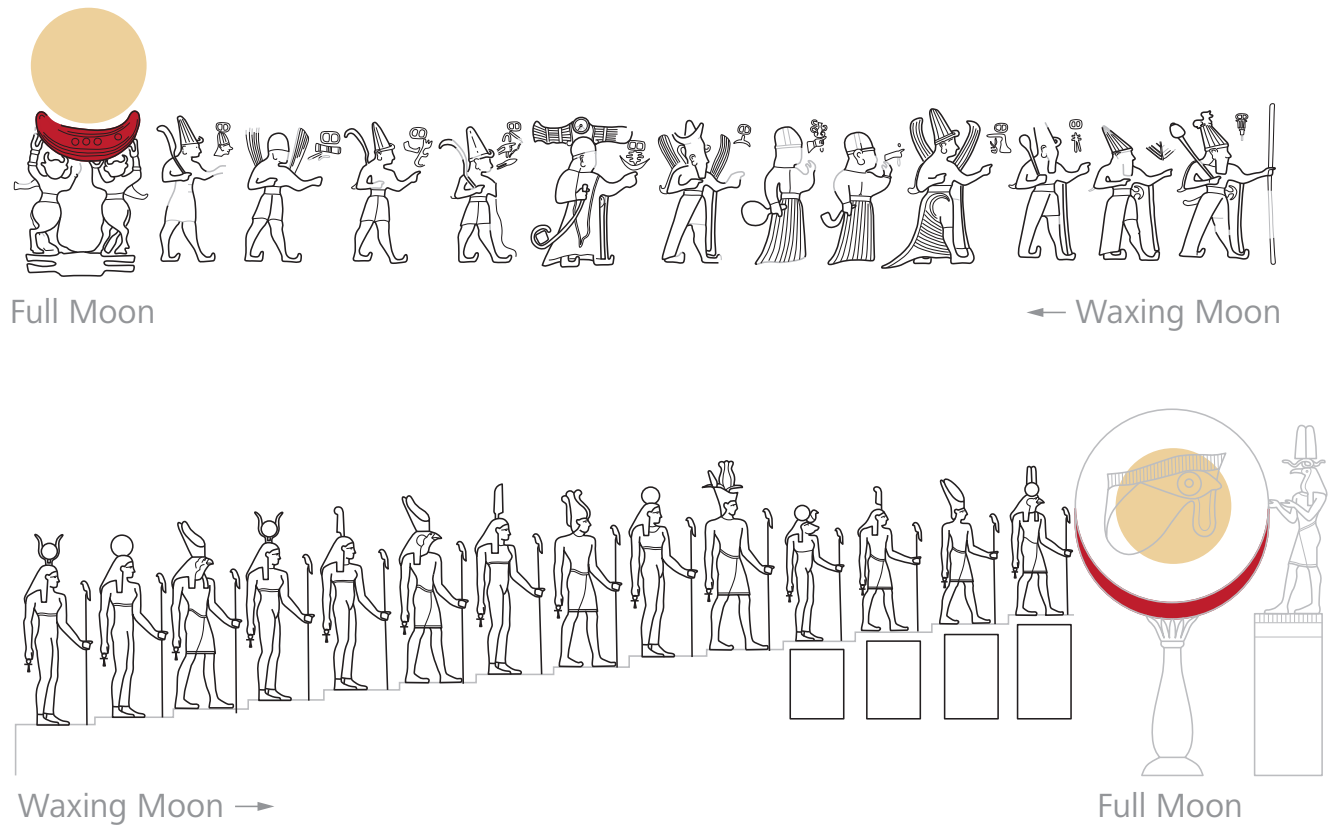

FIGURE 3. Waxing days of the lunar month depicted as Hittite deities in Yazllıkaya's Chamber A (Reliefs 28-41) and - nearly 1200 years later and $2000 \mathrm{~km}$ away - as Egyptian deities in the Temple of Hathor at Dendera.

The symbolic meaning of Reliefs 13-41 also may borrow from the Creation myth narrated in the Enüma Eliš (after its opening words: "When on high"), as recorded on seven clay tablets comprising a thousand lines and dating most likely to the second half of the second millennium BC (Brandes 2020, 211). This Mesopotamian text is roughly contemporary with the Yazlıkaya reliefs. At the opening of Enūma Eliš Tablet V1-2, Marduk creates "the stations for the great gods" and positions "the stars which correspond to them" (Rochberg 2016, 195). These stars were associated with a 360-day year that, as discussed above, was used in Mesopotamia as prime unit of time (Brandes 2020, 213). The myth describes the origin of the cosmos, its structure, its function and astronomical cycles of time. Marduk divided the year into 12 months and associated each of them with three stars, for a total of 36. The Enüma Eliš also has clear intertextual references to the so-called "astrolabes" and MUL.APIN. That text makes it clear that rising stars were linked to fixed days in the above-mentioned schematic calendar. MUL.APIN also provides fixed dates for the solstices and equinoxes. The schematic calendar was an important tool which opened up the possibility of giving fixed dates for astronomical phenomena - a possibility lacking in the framework of a lunisolar calendar. 


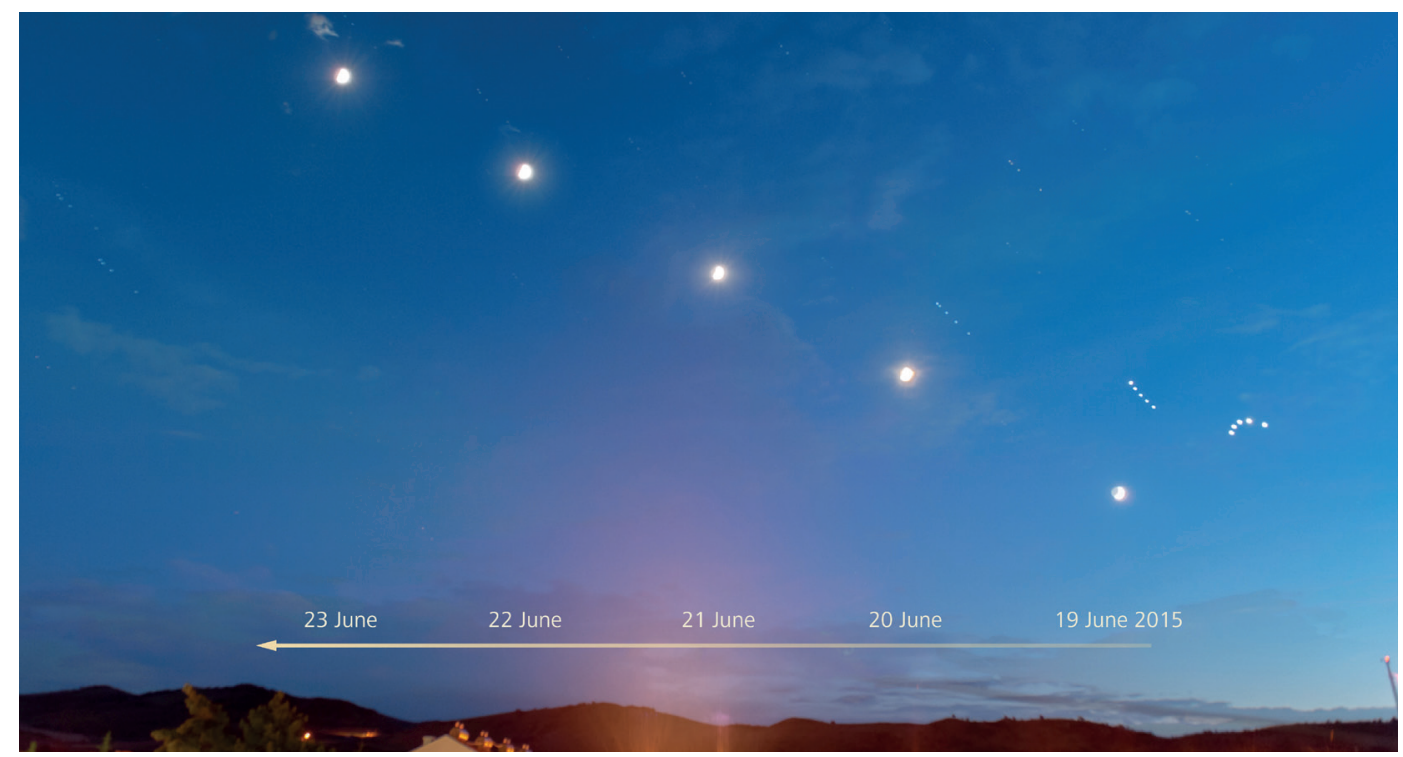

FIGURE 4. The position of the Moon in front of different asterisms at midnight during five consecutive nights (19th-23rd June 2015) in Boğazkale. At the time, Jupiter and Venus shone brightly.

Enuma Anu Enlil, a collection of over 6500 Mesopotamian omens, contains a passage related to the Creation, at the end of Tablet 22, that says Anu, Enlil and Ea "draw" the constellations as likenesses of the gods. Although the Yazlıkaya day-count figures total 30 , and not three (for a month) or 36 (for a year), the astral character of some of the Hittite figures indicates that broader celestial symbolism plays a role in this display and perhaps links stars to the calendar.

When viewed from the earth, the Moon appears near a different celestial group or prominent star each night (Figure 4), and night by night it moves farther to the left until it returns to the first asterism on the path of the Moon after one sidereal lunar month of 27 or 28 days. Observations of the Moon or a planet past certain reference stars were common. Sometimes called "normal stars" (Jones 2004, 481; Hunger 2014), they marked the Moon's progress along its path. Often, although not always, the Moon's path was divided into 27 or 28 such segments relative to fixed stars, and the Moon's position with respect to those zones provided a lunar measure, or "mansion". Because the Moon plays a role in astrological divination, its position with respect to reference stars along its path through the night sky is noted in texts. The Moon's path is close to, but not identical with, the ecliptic, which the Sun follows through the background stars. These stars are part of the framework for major astrological texts, including the "astrolabes", MUL.APIN, the Great Star List and Enuma Anu Enlil (Rochberg 2016, 195).

Sumerian and Akkadian lists of stars and constellations close to the ecliptic occur in cuneiform texts from the third millennium $B C$ until the early first millennium $A D$, but the lists were never standardised into a single set. After cuneiform was replaced by alphabetic script, the lists survived in many different forms and languages (see examples given 
below). Star catalogues provided reference points for tracking the movements of objects - primarily the Sun, the Moon and the five planets visible to the unaided eye. While the so-called "lunar mansions", or stellar references on the Moon's path, are today considered "a mere astronomical curiosity" that does not attract much attention and is virtually nonexistent in astronomy textbooks, the concept was highly effective for time reckoning in the past and as such spread across much of Europe and Asia (Weinstock 1949, 48). A Greek star list was published by Athanasius Kircher in 1643 (Weinstock 1949, 51-52). Lunar mansions were called harrân ${ }^{d} \operatorname{Sin}$ ("The Path of the Moon") in ancient Babylonian (Ginzel 1901, 12; 1906, 70; Weidner 1931, 172), nakșatra in Sanskrit (Ôhashi 2015, 1952), khûrdac in Persian and manāzil al-qamar in Arabic (Qur'ān 10:5, 36:39). In particular, tablet HS 1897 from Kassite period Nippur (c. 1250 BC) names 10 stars for each of the three paths of Anu, Enlil and Ea (Horowitz 2015, 1831), so that, perhaps fortuitously, it matches the number of figures in this group of Yazllıkaya's reliefs.

Because these systems of stellar references vary in number and for the most part depart from 30, the 30 gods depicted in Yazlıkaya Reliefs 13-41 cannot readily be correlated to any sequence of stars by which the Moon's monthly migration was measured. It is also not reasonable to equate the 30 gods with stellar references spaced every 12 degrees along the ecliptic to mark the annual progress of the Sun. The celestial character of several of the 30 divine figures for the 30 days of the lunar month prompts speculation, however, that some of these gods may represent important reference stars on the path of the Moon and so endow figures with multiple meaning.

Wayne Horowitz emphasises that documents like the Babylonian "astrolabes" should not be regarded as completely accurate expositions of astronomical information. They instead merge religious and mythological notions with observational data (Horowitz 2015,1831 ). Because most of the 30 reliefs have celestial identities unrelated to counting the days of the Moon's phases, taken as a set they seem to introduce celestial elements into a shrine where principles of cosmic order apparently converge: Relief 34, the Sun god of the Heaven, is either the divine personification of the Sun or the god associated with the Sun; Relief 35 is either the divine personification of the Moon or the god associated with the Moon; Relief 38 (Šauška/lštar) is either the personification of the planet Venus or the goddess associated with the planet; and Relief 39, the god Ea, was in Mesopotamia explicitly associated with the stars of the Great Square of Pegasus the Winged Horse. Also, the bull-men (Reliefs 28-29) stand on a platform that is embedded in the ground and bears the form of the Luwian hieroglyphic sign for "Earth" while they hold the sign for "sky" above their extended arms. The latter has been interpreted by us as symbolising "the boat of light" (Bittel 1970, 96; Cohen 1993, 141-142; 2015, 222; Pizzimenti 2013, 267; Zangger and Gautschy 2019, 14). This recalls a seventh-century BC Sumerian and Akkadian literary text. In the Sumerian version, it states:

When Anu, Enlil, and Enki, the great gods, by their decisive counsel established the profound rites of heaven and earth, (and) the crescent-boat shape of the moon, the waxing of the crescent moon giving birth to the month, establishing an ominous sign of heaven and earth; the celestial boat (= gibbous moon) they made to appear, and it (too) came out to be seen in the sky. (translated in Rochberg 2016, 71) 
We are not aiming here to link all of the deities depicted in Reliefs 13 to 41 with constellations along the ecliptic or the path of the Moon, but it appears that many of these had celestial connotations and so not only operated as day counters but symbolised primary components of the heavens to confer cosmological symbolism on the Yazılıkaya shrine. The originally Babylonian distinction between supreme and subordinate celestial deities (Haas 2011, 165) is prominently reflected in Yazılıkaya's pantheon. Of the supreme Sumerian astral triad (An, Enlil, Ea), Enlil was replaced by Marduk in Babylonia and is depicted in the form of the Hurrian Teššub in Yazılıkaya. Ea is named as such in Relief 39. The Moon ( ${ }^{\mathrm{DLUNE}}=K u$ šuh) in Relief 35, the Sun (Ištanu ${ }^{\mathrm{D} U T U . A N=S ̌ i m e g i) ~ i n ~ R e l i e f ~} 34$ and the planet Venus (Šauška/lštar) in Relief 38 are represented, and so is Nergal, who continued to govern the underworld, in Relief 82 (Laroche 1952, 120; Eliade 1978, 68).

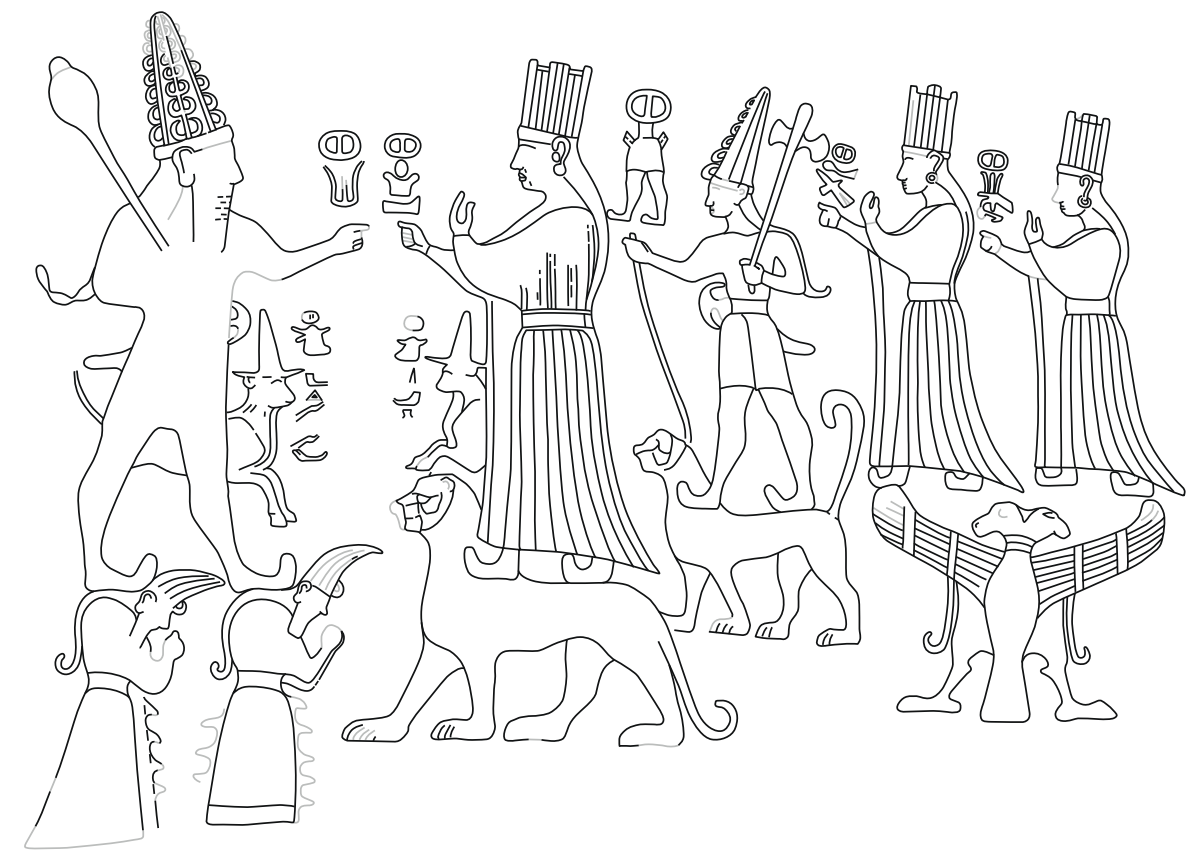

FIGURE 5. Climactic scene (Reliefs 42-46) showing the chief deities Teššub and Hebat including the "bull calf of Teššub" behind the latter.

\section{Yazilıkaya's Main Panel: Symbol of the Northern Sky}

The highest gods of the Hittite pantheon appear on the central panel of Chamber A (Reliefs 42-46; Figure 5). It is the climactic scene, for all of the other figures on the chamber's rock walls parade from both directions toward them. While each of these central divinities certainly represents their obvious individual vocations, they may have also carried multiple meaning in their historical context.

These central gods residing on the chamber's north face rule over the entire pantheon, which is symbolised by the rest of the figures. This zone in the chamber, by 
its position to the north and at the focus of an assembly of celestial and cosmic gods, reasonably references the northern celestial realm, centred on the north celestial pole and hosting the circumpolar constellations. The north celestial pole is the unmoving spot around which the sky, and so the entire universe, seems to turn. In traditional cosmology, it stabilises the cosmos and governs its behaviour. The supreme god is often imagined to preside at the top of the sky and is frequently associated with a high mountain and world order.

In the central relief, Teššub and the other high gods are affiliated with the north. They are not the same as stars of the circumpolar realm, but they appear to be allied with that realm. Their cosmological status could be compared to the ancient Norse gods who resided in Asgard at the summit of the cosmic ash tree that pointed toward the north celestial pole and that symbolised the axis mundi.

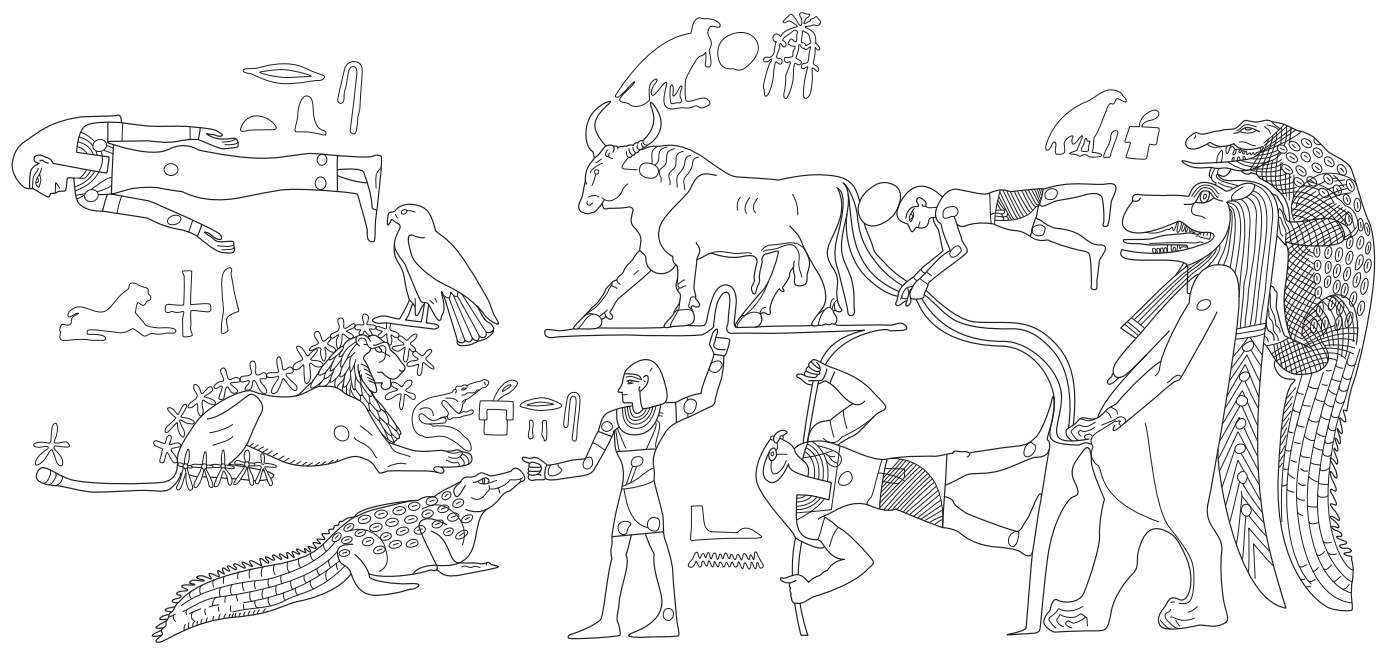

FIGURE 6. Astronomical ceiling of tomb KV17 of Pharaoh Seti I, a reflection of the northern night sky.

Although the same cannot be proved of Olympus, where Zeus and the Olympian gods reside, that summit has attributes of a world-axis mountain and puts the highest gods in the heavens at the top of the cosmos. At Yazllıkaya, Teššub, in Relief 42, stands on two mountain gods, which are meant to emphasise the celestial territory of the highest deity, and this, according to Winckler $(1907,107)$, is the essence of "God". The place where Teššub's and Hebat's hands almost touch at the north point - because they are in the northern celestial realm - corresponds to the north celestial pole.

Similar concepts prevailed in Imperial China, where the emperor was regarded as the terrestrial counterpart of the north celestial pole, the "centre" of the sky, and presided 
at the centre of the world (Krupp 1984, 3). In ancient Egypt the northern stars were considered to be "imperishable" or "undying" and therefore as signifying eternal life. In Pyramid Texts from the third millennium BC, the deceased pharaoh ascends to heaven and becomes an imperishable star. The ancient Egyptians also imagined the deceased pharaoh joining the Sun god in his solar boat, an idea that persisted in the era of the Hittites and Yazılıkaya. Nevertheless, circumpolar stars belonged to Egypt's northern group of constellations, which are depicted in several tombs of New Kingdom pharaohs, including on the famous astronomical ceiling in tomb KV17, belonging to Pharaoh Seti I (c. 1290-1279 BC), in the Valley of the Kings (Figure 6 - Krupp 1984, 299; Spence 2010, 174; Allen 2015, 9; Quack 2018, 65).

Placing Hebat in the northern and circumpolar group may seem to contradict her role as an equivalent of the sun goddess of Arinna, but such metaphors are not necessarily maps of the heavens. They instead emphasise relationships and divine function. Hebat's solar connotation, in fact, is even more complex. She was never a solar deity in her purely Hurrian milieu (Bryce 2002, 137), and her origin most likely has prehistoric roots. In Hittite cuneiform texts describing the worship of the sun goddess of Arinna, she is called Vurušemu or Arinitti(ya) - "The Queen of the Heaven and Land of Hatti". Hebat probably entered the Hittite pantheon as the consort of Teššub, and people at the time wanted her to be equated with the Sun goddess (KUB 29.8 I 11, 21.27 I 3). Anatolian Hattic tradition knew another Sun deity, the male Eştan, Hittite Istanu, representing the Sun as a daytime star (Haas 2011, 226; Klinger 1996, 144) and as such the guardian of the state and the king in war (KBo 3.4. I 16-29).

How the Sun goddess was actually related to the Sun is not yet known. We do know that she was also associated with the earth and the underworld as the Sun goddess of the Earth, which makes her a kind of Mother Earth. She is clearly a high god, not onedimensional, and not confined to a narrow astronomical function. She borrows meaning from the Sun and the Earth and other aspects of the world to indicate her powers and her responsibilities, and as divine ruler she may also be linked to the northern, circumpolar realm. In Hittite religion other goddesses were also associated with the Sun and the Earth/netherworld (Haas 1994, 131-133; Kassian and Yakubovich 2004, 406-407), which were apparently all perceived as female.

A second solar cult in Hittite religion, however, is male in character and related to justice (KUB 6.43 III 15-17). The Sun god of the heaven in Hatti (Relief 34), named Šimegi in Hurri, was derived from Šamaš in the Mesopotamian tradition (Beckman 2012b, 129). The two cults with the male and female features of the Sun are clearly separated from each other (KUB 6.45, 30.14 I 1-9).

The final group in Chamber A consists of the procession of female deities on the eastern wall (Reliefs 46a-63). Seventeen of these are still preserved and two more appear to have belonged there (Zangger and Gautschy 2019,14). These deities are again almost identical in appearance, but most of those closer to the north bear names. In our model, these figures reflect the female character of the solar year (Bryce 2002, 142). They were used to keep track of and display years and would thus have played an important role in synchronising lunar months and solar years. 
We suggest that Chamber $A$ as a whole can be viewed as symbolising everything on Earth and in heaven, including the Sun, the Moon, the five visible planets, some constellations and stars, the north celestial pole and the northern circumpolar realm. If this interpretation can be confirmed by new observations and additional evidence, a new approach to understanding Hittite religion may be opened.

Gregory McMahon $(1995,1983)$ has emphasised that there are significant differences between gods in Hittite texts and gods depicted at Yazılıkaya, where the influence of Luwian and Hurrian belief is evident. Nonetheless, Yazılıkaya is basically a pictorial counterpart to the lists of deities who figure in prayers, festival texts and treaties (Bryce 2002, 161; Haas 2002, 108; 2011, 174). At Yazllıkaya, the disposition of the gods seems to adhere to a broad celestial scheme, and Hittite invocations specifically addressed gods in the sky:

The Lulahhi-god, the Hapiri-gods, all the gods of Hatti, the god of heaven, the god of earth, the mountain, river, springs, clouds, sky, earth and the Great Sea.

(translated in Hawkins 1998, 65)

Hittite research has, to this point, emphasised gods of mountains, caves, lakes and grottos, as well as extispicy (D'Agostino et al. 2015), and what has been achieved in those inquiries remains unchallenged. Hittite religion, however, evidently also contained a significant astral component, a premise reinforced by texts as well as by earlier research (GonzálezGarcía and Belmonte 2011; 2014; Belmonte and González-García 2014; 2015). Because traditional cosmology is metaphorical and describes abstract relationships, devoid of tangible geography and time, it is neither simple nor consistent. It is a unification of disparate data into an ordered interdependent whole.

\section{Yazilıkaya's Chamber B: Symbol of the Netherworld}

Our treatment of the astronomical function and metaphorical meaning of elements in the Hittite rock sanctuary of Yazllıkaya has concentrated on the interpretation of the processions of 64 preserved (and two removed but once present) deities in Chamber A (Figure 2, above). The approach suggests it is also appropriate to examine Chamber $B$ (Figure 7) for symbolic complexity, which may still be to some extent unrecognised.

As shown in Figure 7, Chamber B is a narrow cleft enclosed by vertical western and eastern walls. These rise up to $12 \mathrm{~m}$ above present ground level. The exceptionally perpendicular surface of the western wall runs north-south, within a deviation of about $5^{\circ}$. This wall contains only one relief panel, depicting 12 uniform male figures, similar to Reliefs 1-12 in Chamber A. These 12 gods of the underworld (Figure 8, Reliefs 69-80 Güterbock 1975b, 191-192), as they are commonly interpreted, carry sickle-shaped swords resting on their shoulders. We suggest that the two oblong niches in the western wall (plus one in the eastern wall) could have accommodated tools for observing the stars and for night timekeeping. The tallest relief of the sanctuary is on the eastern wall. It is $3.4 \mathrm{~m}$ high and comprises a human head, with a horned, conical hat, four lions - two with their heads hanging down (Figure 9, Relief 82) - and a majestic sword. The lions appear to form 


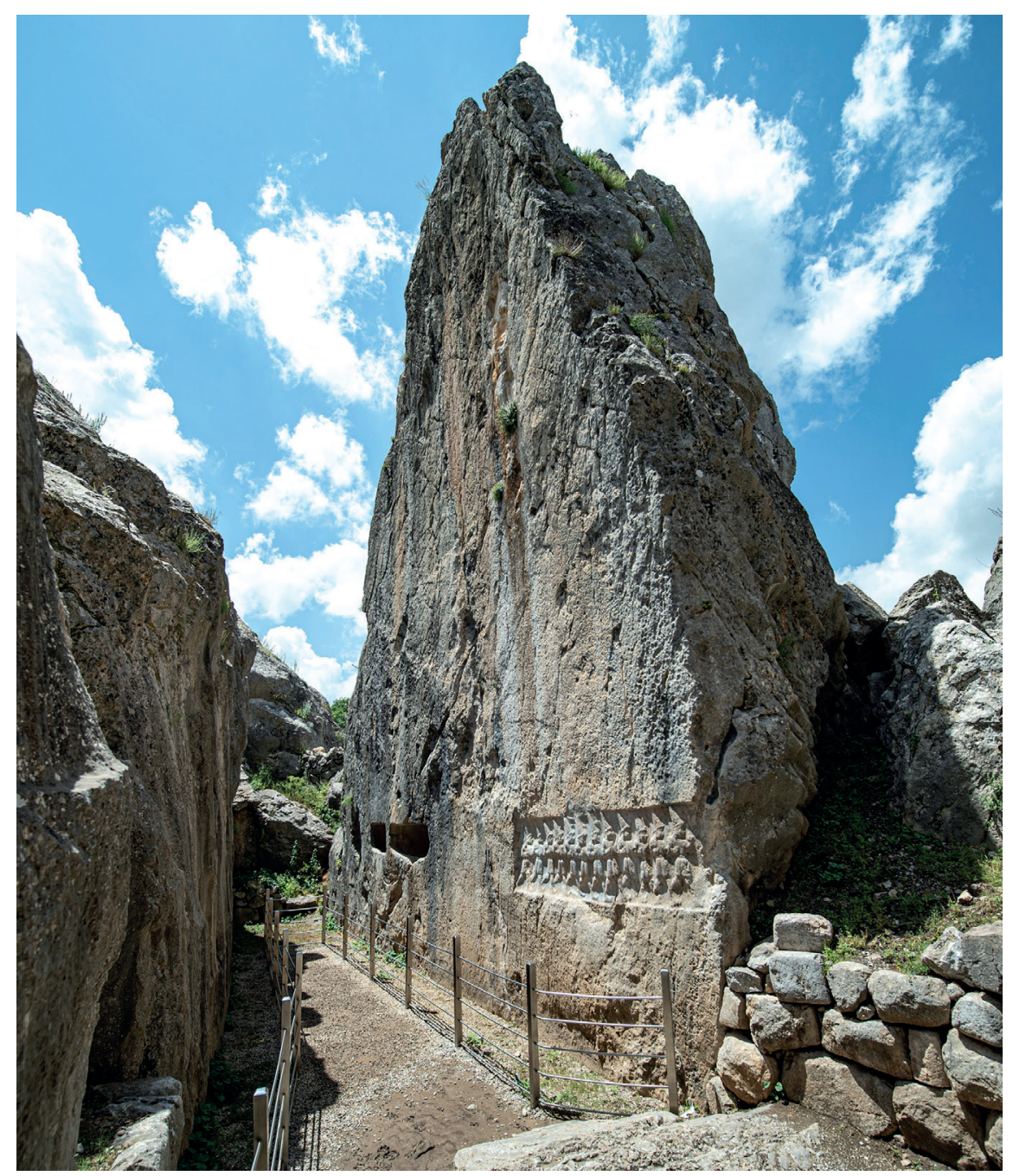

FIGURE 7. Chamber B, looking southwest, showing the $12 \mathrm{~m}$ tall western wall with its panel of 12 gods of the underworld (Reliefs 69-80) and two niches in the background.

the sword's hilt, and the blade plunges vertically into the ground. Many scholars consider this relief to represent the Hittite version of Nergal (Bryce 2019, 244), who is known as the underworld god in Sumer and Akkad and whose symbol is the sword. The expressions "the bronze swords of Nergal" and "the twelve gods of the crossroads" in Hittite cuneiform texts suggest an association of these reliefs with the underworld (Güterbock 1965, 198; Gurney 1977, 22-23; Bittel 1970, 110; 1980, 22). Nergal also shares some common features with the Mesopotamian Sun god Šamaš. In a Mesopotamian hymn text, Nergal is called the "King of the Sunset" (Zólyomi 2010, 419) and thus represents the Sun god during his stay in the netherworld at night and in the winter (Winckler 1903, 40; McMahon 1995, 1985). 


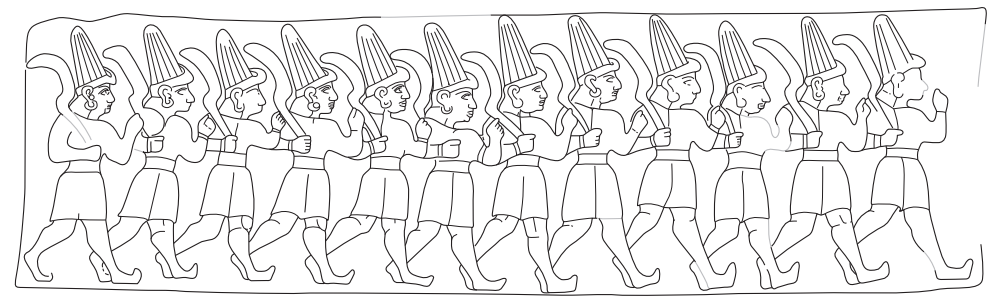

FIGURE 8. The 12 gods of the underworld (Reliefs 69-80) in Chamber B carry sickle-shaped swords on their shoulders.

The eastern wall of Chamber B also contains a relief of Great King Tudhaliya IV under the patronage of the god Šarruma (Relief 81). Such a depiction of the king, under the auspices of a god (Umarmungsszene), has also been transmitted on seals of Muwatalli II and Muršili III (Herbordt et al. 2011, 94; Cammarosano 2018, 67, 302) but is otherwise foreign to Hittite iconography.

With respect to the interpretation of Chamber $B^{\prime} s$ meaning and function, experts on Hittite religion have not yet reached a consensus. A tablet found in 1961 (KBo XII 38; Otten 1963, 16-19) contains two texts of Šuppiluliuma II which may have been drafts for a monumental inscription in hieroglyphic Luwian (Güterbock 1967, 81). One of these documents, a version of the annals of Tudhaliya IV, says that the actual text has been inscribed on a commemorative statue set up for him in an "eternal hekur" (NA4 hekur SAG.UŠ). Otten $(1963,22)$ considered this to be Chamber B in Yazılıkaya, although alternatives have also been proposed (Gurney 1977, 42-43; Hawkins $1998,72)$. The current excavator deems Chamber B to have served in the mortuary cult of the deceased king Tudhaliya IV. Accordingly, it would have been established during the reign of Šuppiluliuma II, at the end of the thirteenth century $B C$ and thus considerably after Chamber A (Schachner 2011, 103; see also Otten 1967, 234). Some scholars, however, argue that the regalia of Tudhaliya IV are identical with those of the Sun god (Beckman 2012a, 607). The great king may thus have claimed divine status for himself while

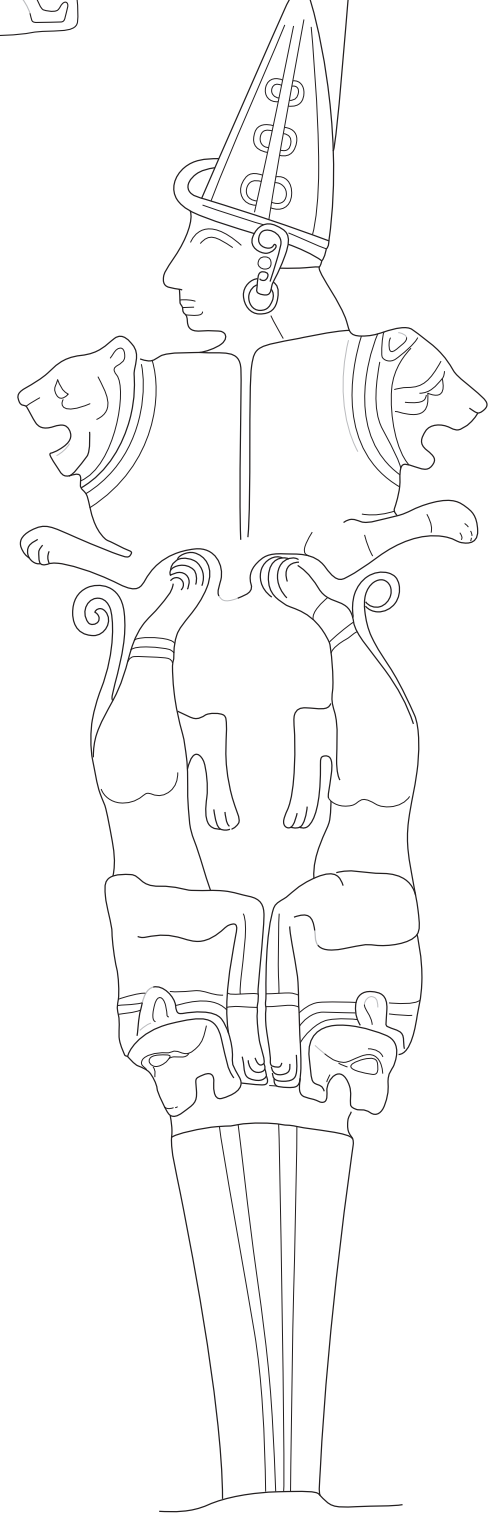

FIGURE 9. The relief of Nergal, the sword god of the underworld in Chamber $\mathrm{B}$, is $3.4 \mathrm{~m}$ tall. 
he was still alive and so increasingly portrayed himself not just as the one favoured by the gods but as a god himself (Bryce 2019, 102, 106).

We have previously interpreted Chamber B as an astronomical instrument, some sort of an observatory used for measuring time during the night through observing stellar motion against the high edges of the rocky walls to the north (Zangger and Gautschy 2019, 19-21). The sharp edges of the highest rock could have been employed to determine the culmination of certain stars or asterisms and so establish a specific hour in a particular month to within a precision of about 10 minutes. From Mesopotamian sources it is known that recordings of such observations were made in units of "cubits" and "fingers" (Rochberg 2016, 217). In New Kingdom Egypt, on the other hand, transits of stars seem to have been specified in terms of human anatomy (for example "left eye" or "right ear"), and Quack $(2018,63)$ has argued that these probably refer to a human statue set up directly opposite the observer as a marker of the meridian. The latter cannot be proven unambiguously - no such statue was found in place in Egypt, but it seems likely considering the depictions of the star clocks in some Ramesside tombs. In Yazılıkaya's Chamber B, a stone block, $1.4 \mathrm{~m}$ wide and interpreted as a statue base, was found at the north end of the chamber (Seeher 2011, 100, 115). A statue standing at least $3 \mathrm{~m}$ tall is imagined to have stood on this block (Macqueen 1986, 132; Seeher 2020, 165), and if this were the case it would have been well placed for transit measurements like those proposed for Egypt.

Even if it were possible to monitor the stars over the course of the night for timekeeping, this neither explains the function of Chamber B nor the purpose of the timekeeping. The information that was gathered probably did not leave the premises, and in any case, municipal timekeeping during the nights would have been of questionable use. If timekeeping at night were part of Chamber B's function and purpose, it could have possibly been related to activities serving other purposes, such as electing the right prayer to be recited at a specific time. It may therefore be assumed that the purpose of Chamber B was not merely that of time reckoning, but instead, it had to have the ability to tell time to ensure what was supposed to be done there was done correctly.

If Chamber A symbolises the earth and the sky, Chamber B's affiliation with a subterranean netherworld makes sense. The complex as a whole then embodies the entire cosmos - underworld, surface world and celestial world - and symbolically connects the three primary realms of a traditional cosmology at an umbilical point, perhaps then also recognised as the centre of the world.

Several facts reinforce this function for Chamber B. Hittitologists have long argued that "the strong underworld associations are unmistakable" (Gurney 1977, 41). Hugo Winckler, the first epigraphist and excavator of Hattuša, had recognised many of the Near Eastern mythological connotations and festival sequences even before his fieldwork in Hattuša began in 1906. At the time, his observations had to be based exclusively on Mesopotamian and Egyptian documents. While the highest Mesopotamian god Marduk ruled over the cosmos, Nergal reigned in the underworld. The asterism belonging to him was the Pleiades, and their annual disappearance for 40 days from the celestial dome symbolised the time when the Sun god lingered in the netherworld (Winckler 
1903, 40). This disappearance of the Pleiades from the sky may be reflected in the duration of the AN.TAH.ŠUM festival, which lasted 38 days (González-García and Belmonte 2014, 322-323). In many customs and religions, this timespan plays a significant role. It occurs in Hesiod's Works and Days (383-387) and to this day still marks the period between Easter and Ascension in Christian calendars. In Syria, the wind blowing in spring is called 'arba'in, which means "forty" [days] (Winckler 1903, 66n1).

While the north is the realm of the heavens, the south belongs to the netherworld (Winckler 1903, 51); worshipping both was equally important in the Bronze Age. For example, the Adonis sanctuary at Ghineh in Lebanon has a narrow passage that was artificially hewn into the bedrock, and passing through this narrow gap was a symbol for moving through the solstice (Winckler 1903, $64 n 1)$. Such a narrow and largely human-made passage also forms the entrance to Chamber B at Yazilıkaya (Figure 10 - Seeher 2011, 93),

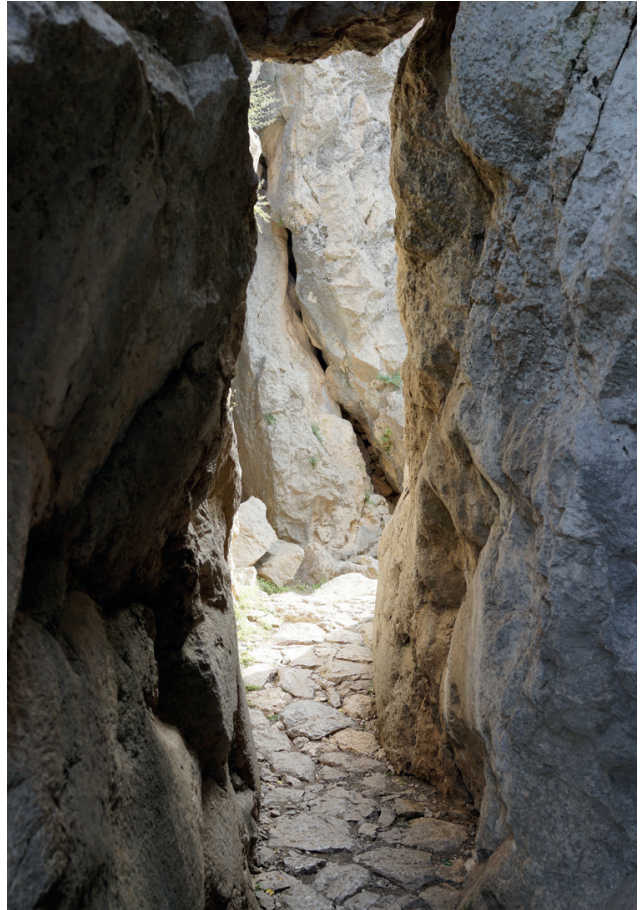

FIGURE 10. The passage to Chamber B was artificially cut through the bedrock and is only $80 \mathrm{~cm}$ wide at its narrowest point. whereas the plan of the temple buildings in front of it made reference to the direction of the setting Sun at the summer and winter solstices (Zangger and Gautschy 2019, 9). The symbolism highlighting the solstice and the passage into the netherworld was even further enhanced with an artificial water pipe going right through the entrance to Chamber B (Naumann 1975, 117-119): water had the status of a passageway and specifically marked the passage to the netherworld (Erbil and Mouton 2012, 61, 72). In addition, excavations in Chamber B have brought to light remains of birds, possibly indicating specific sacrificial rituals of the underworld (Bittel 1970, 109; Cimok 2008, 137).

The iconography of Chamber B reflects death, but it is a temporary death - the dying of the Sun at night, the time the Sun spends in the south during the winter and the temporary vanishing of the Pleiades and other stars after heliacal setting. It is a death that is eventually overcome by the perennial celestial cycles. The philologist and scholar of religions J. G. Frazer (1914, 41-43) draws attention to Anatolian customs that were described by Plutarch: "The Phrygians imagine that the god sleeps in winter and awakes in summer, and accordingly they celebrate with Bacchic rites the putting him to bed in winter and his awakening in summer" (On the Worship of Isis and Osiris 69 [= Moralia 378e]; see also Steiner 2001, 162). An earlier version of this symbolism is found in the disappearing god myths in Hattian mythology. In the best-known version of this narrative, 


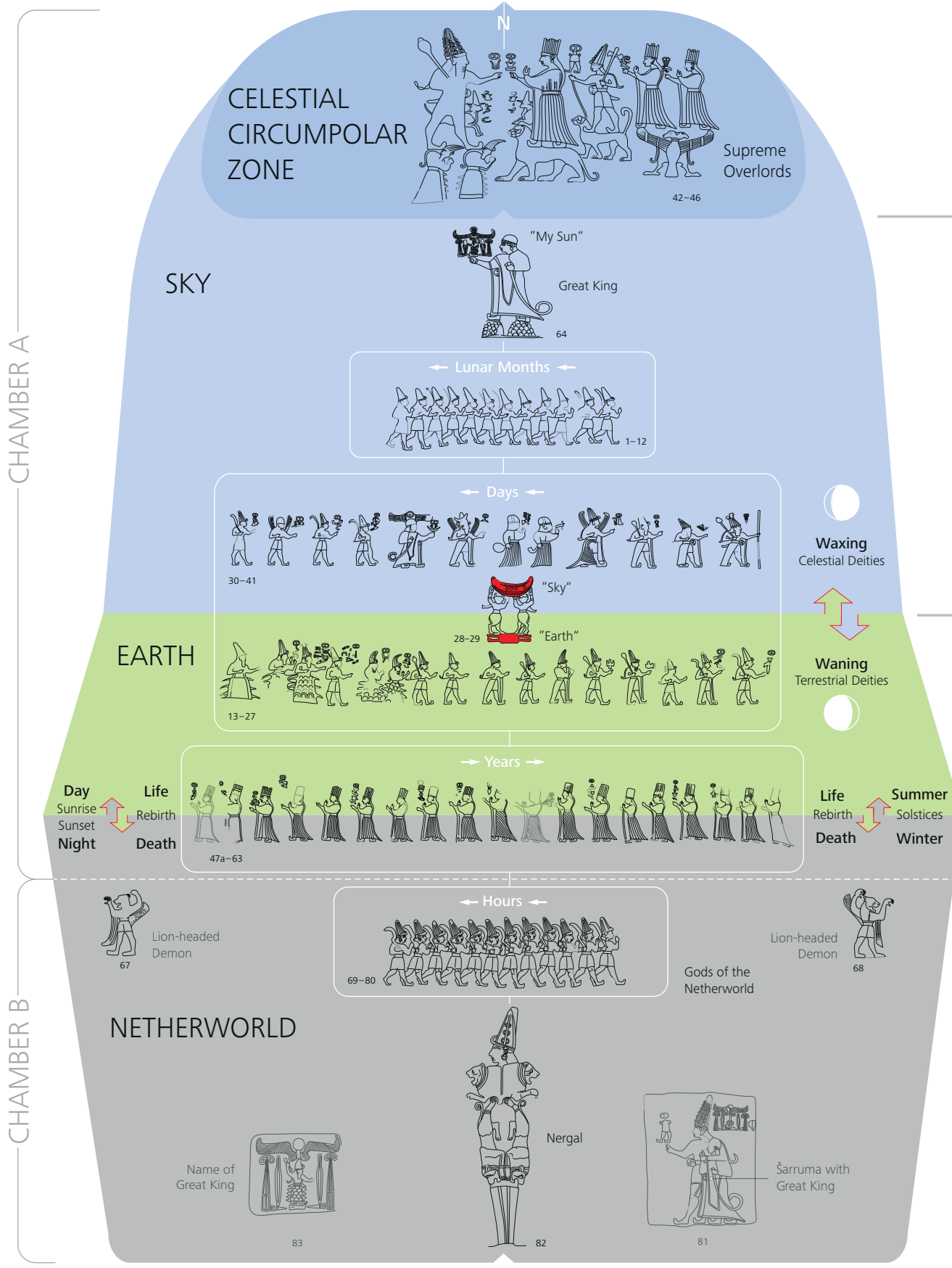

FIGURE 11. Proposal for the cosmological model depicted in Yazlıkaya, including all reliefs of deities and emphasising the groups they form and how these are related to each other to symbolise recurring celestial cycles. 
the myth of Telipinu, the disappearance of the god indicates winter, and his presence represents summer (Hoffner 1990, 14-17).

The rock sanctuary of Yazılıkaya may, then, recapitulate the structure of the traditional universe - the Earth and the celestial realm in Chamber $A$ and the netherworld in Chamber $B$ (Figure 11 and 12). In Chamber A, three parts are distinguished. First, there is the Earth's surface. Second is the part of the sky containing the seasonal stars, northern stars, the Moon, the Sun and the planets; Tašmišu, the storm god of Hatti (Relief 41), determines the fate of this part of the universe and leads a large fraction of the pantheon (Relief 13-40). Third, the far north end of the shrine may mirror part of the celestial vault associated with the supreme deities Teššub (Relief 42), his wife and children and a grandchild. The netherworld, comprising the southern horizon and the oceanic depths, is epitomised in Chamber $B$ and ruled by Nergal.

\section{Roots of Celestial Aspects of Hittite Religion}

The interpretation of Yazılıkaya as a sanctuary that had been conceived to model a cosmos populated with celestial divinities advances arguments on astral symbolism following a long tradition of, for the most part, incredibly prolific and imaginative scholars who have stressed the importance of the sky in ancient belief systems. Among these are J. G. Frazer (1890), Eduard Stucken (1896-1907), Hugo Winckler (1903; 1904; 1907), Alfred Jeremias (1909; 1929), Mircea Eliade (1954; 1957; 1978), E.C. Krupp (1997b; 2000; 2005), and Volkert Haas (Haas 2002; 2011). Even though their tautologies largely reinforce one another, few of these researchers were prepared to reference each other's work. Another commonality is that the twentieth-century research, for a variety of reasons, has been deemed eccentric and erratic and is therefore rarely exploited.

One reason why there has been a reluctance to take the work of Hugo Winckler and Alfred Jeremias - and to some extent that of Mircea Eliade - seriously is because it is associated with the late nineteenth-century pan-Babylonian school of thought. This model notoriously overreached, for instance, when it claimed archaic detailed knowledge of precession or when it extracted elaborately coded astronomical language in myth worldwide as the result of a diffusion of ancient Mesopotamian star lore - a claim going far beyond what the evidence allows (Thompson 2020). As originally conceived and applied, pan-Babylonism is now undoubtedly discredited. It falls short, for example, with details of Hebraic tradition, with diffusion of Babylonian wisdom worldwide and with the practice of explaining everything in mythology in terms of astronomical metaphor. The pan-Babylonists had a completely inaccurate understanding of the character and antiquity of ancient Babylonian astronomy, and when that was made clear, Assyriologists and cuneiform experts wanted nothing to do with any of the astral myth and cosmological symbolism.

The reference to arguments first advanced by Hugo Winckler, as we make here, does not imply that we embrace his entire vision of antiquity. Our line of inquiry is not dependent on pan-Babylonist doctrine, but recognises the use of astronomical symbolism wherever it may emerge. Certain astral and cosmic themes remain sustainable and are unencumbered by claims for the universal meaning of myth. It would be unwise 
to assert that every idea that arose from pan-Babylonists is wrong and that there is no Mesopotamian influence in the Middle East. Some of the broad themes identified by the pan-Babylonists have merit when examined cross-culturally in practical uses of the sky that are encountered around the world. These did not all diffuse out of Babylon, but because the sky is a resource all people find useful, the themes are widespread.

The Romanian émigré-scholar Mircea Eliade, in particular, advanced concepts that help with interpreting the history of religion in Neolithic and Bronze Age Anatolia. Eliade documented in a number of ancient civilisations an "archaic ontology" according to which the terrestrial realm is a human-made copy of the celestial. The Hermetic maxim "as above, so below" thus became his imperative, and as such a key to understanding imperial cosmologies from Eurasia to Mesoamerica (Smith 2005, xiii). His life work has been regarded as "an exercise of a synthetic imagination which forges a coherent whole out of apparently disparate items" (Smith 2005, xii). Even though Eliade saw himself within the scholarly and theological tradition of the pan-Babylonian school (Smith 2005, xvii), he apparently never quoted Winckler. During his lifetime Eliade was considered a leading authority in the domain of history of religions (Ginzburg 2010, 307); revelations about his closeness to a right-wing movement as a young man in Romania have since rendered his achievements less appealing to the scholarly community in the Old World, but in Mesoamerican religious studies his approach became an indisputable paradigm, abridged under the term "cosmovision" (Matos Moctezuma 2003).

Eliade was among the first to argue for a surprising religious continuity which prevailed in Anatolia from the seventh millennium BC to the rise of Christianity (Eliade 1978, 139). For instance, seasonal festivals, especially the New Year festival, had been performed in Anatolia from Neolithic times (Eliade 1978, 141). Indo-European immigrants, chief among them Luwians arriving in the third millennium $B C$ and Hittites entering the region in the second millennium BC, to a large extent acquired local belief systems, deities and religious ceremonies through transculturation and syncretism (Goedegebuure 2008, 165). This included the worship of the mother goddess, as well as the Hittite Sun Goddess of Arinna and the Hattian Vurušemu, who is directly derived from the Sumerian-Babylonian netherworld deity Ereškigal (Haas 2011, 223) and who corresponds with the Sun that dwells in the underworld during the night. According to this myth, the Sun is immortal and goes underground into the land of the dead every night. It is stated in the Hittite texts that the Sun goddess of Arinna descended from the sky towards the underground (KUB 36.89 | 3, 38).

Soon after entering Anatolia the Hittites were influenced by the Assyrians, and towards the end of the thirteenth century BC they increasingly borrowed elements of the non-Indo-European Hurrian culture from the northern regions of Mesopotamia and Syria. Many aspects of official Hittite religion, which as depicted in Yazilıkaya was influenced by the Hurrians, can therefore be better understood when Sumerian divinities, metaphysical concepts, symbols, myths, and rites are taken into consideration. For the Sumerians, "every divinity was imagined as a celestial being" (Eliade 1978, 57), and the transcendent, celestial structure of divine beings is indeed confirmed by the determinative sign that precedes their ideograms, which originally represented a star. Volkert Haas 
has even drawn connections from the Sumerians all the way to ancient Greek times (Haas 2011, 184).

Another commonality between the religions of the Mediterranean and the Near East is the principal concept that nature as a whole is animated and permeated by individualised forces; this applies both to the visible material world of the earth as well as to the stars, the sea, lakes, rivers and springs, animals, plants and stones (Haas 2011, 164). A point of departure for all ancient belief systems in the Near East is the conviction that the cosmos and all matter are filled with forces which are related to one another. The natural universe and the social universe were seen as classified through complementary opposition in related pairs of quality or character, such as sick/healthy, impure/pure and sterile/fertile (Haas 2011, 170).

The most important event, and the only one that brought about real change, however, was the emergence of the world through primordial Creation. After that, all changes adhere to the rhythm of the cycle of cosmic order and its immanent periodicities: the motions of the heavenly bodies, the circle of the seasons, the phases of the Moon and the rhythm of vegetation (Eliade 1978, 91). This periodicity of cosmic rhythms constitutes the perfection established in the age of the "First Time". The solemn commemoration of the Enūma Eliš was in effect a re-enactment of the cosmogonic Creation, as is clear from the formulae recited during the ceremony. According to Eliade, "most of the ideas of cycle, dualism, polarity, opposition, conflict, but also of reconciliation of contraries, of coincidentia oppositorum, were either discovered or clarified by virtue of lunar symbolism" (Eliade 1957, 156). The days of the lunar month were used to determine dates in the common calendar, but the phases of the Moon - first appearance, waxing, waning, disappearance, followed by reappearance - also epitomise the cyclical concepts of Near Eastern belief systems (Eliade 1954, 86-87). Lunar symbolism thus helped integrate a vast array of apparently unrelated facts observed in nature into a single system characterised by birth, death and rebirth. Just as the disappearance of the Moon is never final, the disappearance of human beings will never be final (Eliade 1954, 87). Even when entire civilisations suffer natural catastrophes, the calamity is never total because humanity is ever reborn from a pair of survivors - a belief system later endorsed by Plato (Timaeus 22D-23C).

A Hittite, or rather Hurrian, cosmogony is found in the myths surrounding the deity Kumarbi (possibly Relief 40), who bears the Enlil epithet "Father of the Gods". Volkert Haas (2011, 181-182) has argued that individual mythologems of the story surrounding Kumarbi go back to the Ur III period; that is, to the time of the Hurrian-Sumerian contacts at the end of the third millennium BC. The myth relates that before the beginning of the current world order, in the phase of existence that preceded the cosmos, heaven was directly above or even on earth, so that there was no living space between heaven and earth (Haas 2011, 183-184). It was the violent separation of the two that put an end to this bleak state of affairs. The link between heaven and earth may have been a mountain, $a$ tree, a ladder, an umbilical cord or a phallus. When it was broken, the earth became fertile, and an abundance of vegetal and animal life arose: "The most important thing, however, was the emergence of light, that is the Sun, which separates day from night, as well as 
the Moon, which determines the time division into days and months, that is the calendar" (Haas 2011, 184, translated).

The Hittite pantheon, as a consequence of its religious roots going way back in time, thus included an amalgamation of local Anatolian and Hurrian divinities, side-by-side with deities of Sumero-Akkadian stock (Eliade 1978, 139-140). Deities which became part of the Hittite pantheon, including the weather god of Aleppo, Hebat and Ishara, occur already as Syrian gods in texts from Ebla dating to middle of the third millennium (Haas 2011, 162), and specific Hittite rituals on both the living and the deceased had already been performed over a thousand years earlier (around 2350 BC) in Syria (Haas 2011, 162).

Royalty was also held to have descended from the sky (Eliade 1978, 75), and the king was regarded as the son and vicar of the divinity on earth. As such, the sacred king was the highest priest. He bore cosmic responsibilities for maintaining order, for rectifying discrepancies and for subduing disorder. This principle also rests on the notion of old Babylonian kingship as the earthly representation of the omnipresent Sun god who guarantees justice and thus social order. The Hittite king in his ceremonial costume appears as the iconographic apotheosis of the Sun god from the Kültepe period. The garment of the deity (Relief 34), along with his insignia, expresses the identity of the enthroned king. It is in this solar appearance that the king is shown in Yazllıkaya (Relief 64 and 81), and also in Alaça Hoyük and Sirkeli, and on seals of Muwatallis II (Haas 2011, 212). The virtual identity of the Sun god and the king links the cosmic and social order, the mainstay of which is law, without which society would sink into anarchy and chaos. Volkert Haas (2011, 213) concluded that basically "every Hittite great king in his capacity as the guardian of justice represents the Sun god or is a manifestation of the Sun god" (translated). This indispensable unity is expressed in the Hittite royal title "Sun", "our Sun" and "my Sun". Already, Hattušili I described himself as the Sun, and he is also referred to as the Sun in a historical-mythological story (Haas 2011, 213).

The sovereign "was responsible for the regularity of the rhythms of nature and for the good estate of the entire society" (Eliade 1954, 55). It is not clear whether this responsibility also included a ritual hieros gamos of the king with a hierodule personifying the goddess (Eliade 1978, 61, 73-74). Despite absence of information in Hittite texts about the sacred marriage, depictions of the subject exist in Hittite art: vases of the Early Hittite period from Inandık, Bitik and Hüseyindede B are interpreted as scenes of sacred marriage ceremonies (Sipahi 2019, 89). The ceremony was also celebrated in Ugarit and might have been an important element of the Hittite religious year (Lipiński 1986, 215).

The British cultural geographer Paul Wheatley carried the maxim "as above, so below" into the realm of natural sciences by developing a model for comparative studies of the social and religious dimensions of traditional urban settlements all around the globe (Wheatley 1971; Carrasco 2005, 9722). Wheatley identified "an intimate parallelism between the mathematically expressible régimes of the heavens and the biologically determined rhythms of life on earth (as manifested conjointly in the succession of the seasons and the annual cycles of plant regeneration)" (Wheatley 1971, 414). As part of his research, he tried to understand the complex forces that led to the emergence of the first cities, particularly the factors associated with lasting social differentiation. Wherever 
cities emerged (independently from one another), he noted that the earliest foci of power and authority took the form of ceremonial centres, with religious symbolism imprinted deeply on their physiognomy and their operation in the hands of organised priesthoods. In all seven areas studied by Wheatley (northern China, Mesopotamia, Egypt, the Indus Valley, southwest Nigeria, central Mexico and Peru), priest elites formed the primary generation who developed new tools for the development of society (Wheatley 1971, 305). Wheatley succinctly stated that these ceremonial centres functioned as instruments for the dissemination through all levels of society of beliefs which, in turn, enabled the wielders of political power to justify their goals in terms of the basic values of that society, and to present the realisation of class-directed aims as the implementation of collectively desirable policies (Wheatley 1971, 305).

Wheatley's main publication, The Pivot of the Four Quarters, thus made a persuasive and elegant case for relating the study of religion to comparative worldviews and complex social processes, and it stands as a model for comparative studies of the social and religious dimensions of traditional urban settlements. It remains yet to be investigated to what extent the Hittite capital in general and its ceremonial centres in particular reconfirm this model.

\section{Conclusions: Yazılıkaya, a Link in Space and Time}

The rock sanctuary at Yazılıkaya evidently transmits images rooted in the earliest historical civilisation. Both of its chambers are aligned with the meridian and the cosmic axis, or axis mundi (Eliade 1957, 36; 1978, 134) - just like Yerkapı, the uppermost architectural structure of Hattuša (Figure 12) - and consequently, the Hittite ceremonial district has the attributes of the centre of the universe (Krupp 2005, 426). The sanctuary depicts the whole habitable world - earth, heaven, underworld - extending around this centre, the system created by the paradigmatic work of the gods when they organised space into the three cosmic levels. Yazılıkaya even permits the passage from one cosmic region to another - from heaven to earth and from earth to the underworld, in much the same way as it is known from Sumerian cosmology (Eliade 1957, 36-37; Haas 1994, 141-144). The Hittite religious calendar commemorated, within the duration of a year, all the cosmogonic events, and thereby repeated the act of primordial Creation (Eliade 1954, 22). Yazılıkaya also indicates that not just the date for annual festivals but also the timing of liturgy and ceremony could be kept on-site accurately. The system works in perpetuity and can still be activated now.

Interpretation of Yazllıkaya as a way to keep the religious calendar synchronised with the seasons (Zangger and Gautschy 2019) gains additional support from the cosmological symbolism it seems to incorporate. The deities used for counting the days (Reliefs 13-41) display a wide range of personalities, and we suggest that some of them symbolise stars or asterisms, perhaps along the path of the Moon, and other celestial bodies. We interpret the central panel with the supreme deities, at the far north end of Chamber A, as a reference to the northern stars, the north celestial pole, the circumpolar realm and the world axis. Chamber B, on the other hand, appears to have been intended to symbolise the netherworld. The large relief of Nergal, the 12 gods of the underworld, and the narrow 
passageway covered with water are iconographically consistent with this interpretation. Yazılıkaya, in its entirety, then could be perceived as a symbol of the cosmos. Each of its elements complies with this principle and could be explained within the requisite historical and cultural context. The north orientation of Chamber A, Chamber B and Hattuša as a whole mark Yazılıkaya as the spiritual centre of the Hittite world. Some 50 years ago, Kurt Bittel, at the time excavator of Hattuša and Yazılıkaya, concluded: "This, then, is a representation of the powers that link the nether world with the upperworld, the world in which mankind must live" (Bittel 1970, 97).

These conclusions confirm commentary about Eflatun Pinar, a sanctuary focused on a spring. It is said to represent the cosmos (Bachmann and Özenir 2004, 122; Collins 2007, 192), and as early as 1941, Bittel wrote that the ensemble could only be a depiction of the Hittite view of the world (Bittel 1941, 63; see also Haas 1994, 144). At Kuşaklı-Šarišša too, an excavator concluded that "the Hittite planners tried to integrate the main features of the cosmic order into the outline" (Müller-Karpe 2015, 86; see also Müller-Karpe 2017, 16-26). Likewise, our ideas reinforce and expand the initial cosmological interpretation of Yazilıkaya put forward by one of the authors (E. C. Krupp), which focused on the symbolic meaning of the audience of gods in the open-air shrine (Krupp 1997a; 1997b; 2000; 2005). The ritual activity mirrored divine and cosmic renewal and linked the celestial powers to earthly affairs, and so renewed the king's licence to rule and enforced the ideology of kingship.

Previously, we have emphasised how Chamber A and Chamber B could be interpreted as vehicles for astronomical operations. Chamber A could be considered a calendric mechanism that can function as a date "calculator". It would be incorrect, however, to interpret Yazlıkaya primarily as a location for astronomical observation/computation and a place to keep calendric information straight. A large, elaborate, semi-public space would not be required for this. Observatories neither require nor invite audiences. They are places where work gets done. It thus seems more likely that this was a place where astronomical information was displayed so that the shrine in its cosmological entirety conformed to the full expression of cosmic order. Both major chambers of the sanctuary were, above all, ritual spaces that were used as a stage for important ceremonial activity involving some specific audience. The gods were elaborately illustrated on a large scale. This is staging, not merely computation.

When they took heaven (and) earth the gods separated. The upper gods took heaven for themselves, the inferior gods took earth and netherworld for themselves. -CTH 434.1 (Görke 2019, 166)

You, Telipinu, are a noble god. Your worship is firmly established in the Hatti land. In no other land is it so (firmly established).... Lofty temples adorned with silver and gold are yours in the Hatti land.... Festivals too - the monthly festival, the festivals of the cycle of the year, ceremonies of winter, spring, and autumn ... they celebrate for you in the Hatti land.

(KUB 24.1 i 18-27, ii 1-6, translation after Hoffner 2006, 138-139) 


\section{Acknowledgements}

The authors wish to thank the two anonymous reviewers for their rigorous, constructive and exceedingly helpful assessment of the manuscript. This project was funded by Luwian Studies.

\section{Abbreviations}

$C T H=E$. Laroche, 1971. Catalogue des textes des hittites. Paris: Klincksieck. IboT = İstanbul Arkeoloji Müzelerinde bulunan Boğazköy Tableteri. Kbo $=$ Keilschrifttexte aus Boghazköi. KUB = Keilschrifturkunden aus Boghazköi.

\section{References}

Allen, J. P., 2015. The Ancient Egyptian Pyramid Texts. Atlanta, GA: Society of Biblical Literature. https://doi. org/10.1163/15685330-12341304-02

Altmann-wenalIng, V., ZUZUa. "VIe IVOnatreppen als symbolische Abbilder der Mondzunahme". In Zeit in den Kulturen des Altertums - Antike Chronologie im Spiegel der Quellen, edited by R. Färber and R. Gautschy, 137-145. Köln: Böhlau. https://doi.org/10.7788/9783412518172.137

Altmann-Wendling, V., 2020b. “Die 30 Tage des Mondmonats und ihre Schutzgötter". In Zeit in den Kulturen des Altertums - Antike Chronologie im Spiegel der Quellen, edited by R. Färber and R. Gautschy, 117-126. Köln: Böhlau. https://doi.org/10.7788/9783412518172.117

Bachmann, M. and S. Ö. Özenir, 2004. "Das Quellheiligtum Eflatun Pınar". Archäologischer Anzeiger: 85-122.

Beckman, G. M., 2012a. "The Horns of a Dilemma, or On the Divine Nature of the Hittite King". In Organization, Representation, and Symbols of Power in the Ancient Near East: Proceedings of the $54^{\text {th }}$ Rencontre Assyriologique Internationale at Würzburg, 20-25 July 2008, edited by G. Wilhelm, 605-610. Winona Lake, IN: Eisenbrauns. https://doi.org/10.5325/j.ctv1 bxgx80.49

Beckman, G. M., 2012b. "Šamaš Among the Hittites". In Theory and Practice of Knowledge Transfer: Studies in School Education in the Ancient Near East and Beyond - Papers read at a Symposium in Leiden, 17-19 December 2008, edited by W. S. van Egmond and W. H. van Soldt, 129-135. Leiden: Nederlands Instituut voor het Nabije Oosten.

Beckman, G. M., 2013a. "Hittite Religion". In The Cambridge History of Religions in the Ancient World, edited by M. R. Salzman and M. A. Sweeney, 84-101. Cambridge: Cambridge University Press. https://doi.org/10.1017/CHO9781139600507.006

Beckman, G. M., 2013b. "Under the Spell of Babylon: Mesopotamian Influence on the Religion of the Hittites". In Cultures in Contact: From Mesopotamia to the Mediterranean in the Second Millennium B.C., edited by J. Aruz, S. B. Graff and Y. Rakic, 284-297. New York: Metropolitan Museum of Art.

Belmonte, J. A. 2000. "From the Atlas to the Caucasus: The Other Side of the Mediterranean Before Islam". Archaeoastronomy: The Journal of Astronomy in Culture 15: 78-94.

Belmonte, J. A. and A. C. González-García, 2014. "Astral Symbolism and Time-Keeping in the Hittite Culture". In Proceedings of the Eighth International Congress of Hittitology, Warsaw 5-9 September 2011, edited by P. Taracha, 110-123. Warsaw: Agade.

Belmonte, J. A. and A. C. González-García, 2015. "The Pillars of the Earth and the Sky: Capital Cities, Astronomy and Landscape". Journal of Skyscape Archaeology 1 (1): 9-38. https://doi.org/10.1558/jsa.v1i1.26952

Bittel, K., 1941. "Felsbilder und Inschriften". In Yazllıkaya: Architektur, Felsbilder, Inschriften und Kleinfunde, edited by K. Bittel, R. Naumann and H. Otto, 50-151. Leipzig: Hinrichs.

Bittel, K., 1970. Hattusha: The Capital of the Hittites. New York: Oxford University Press.

Bittel, K. 1980. "Der Schwertgott in Yazılıkaya". Anadolu (Anatolia) 21: 21-29. https://doi.org/10.1501/ andl_0000000203 
Blum, W. 2016. Die Erfindung der Zeit. Köln: Fackelträger Verlag.

Brack-Bernsen, L., 1997. Zur Entstehung der Babylonischen Mondtheorie. Stuttgart: Franz Steiner.

Brady, B., 2015. "Star Phases: The Naked-Eye Astronomy of the Old Kingdom Pyramid Texts". In Skycapes: The Role and Importance of the Sky in Archaeology, edited by F. Silva and N. Campion, 77-86. Oxford: Oxbow Books. https://doi.org/10.2307/j.ctvh1dksg.11

Brandes, T., 2020. "Die fünfte Tafel des Enūma elîs". In Zeit in den Kulturen des Altertums - Antike Chronologie im Spiegel der Quellen, edited by R. Färber and R. Gautschy, 209-217. Köln: Böhlau. https://doi. org/10.7788/9783412518172.209

Brugsch H., 1883. Thesaurus inscriptionum Aegyptiacarum. Leipzig: Hinrichs.

Bryce, T. R., 2002. Life and Society in the Hittite World. Oxford: Oxford University Press.

Bryce, T. R., 2019. Warriors of Anatolia - A Concise History of the Hittites. London: I.B.Tauris. http://dx.doi. org/10.5040/9781788318976

Budge, E. A.W., 1904. The Gods of the Egyptians. London: Methuen. https://doi.org/10.4324/9780203040713

Cammarosano, M., 2018. Hittite Local Cults. Writings from the Ancient World 40. Atlanta, GA: SBL Press. https://doi.org/10.2307/j.ctv6ggxkm

Carrasco, D., 2005. “Wheatley, Paul". In Encyclopedia of Religion, edited by L. Jones, 9722-9724. London: Macmillan.

Civil, M., 1994. The Farmer's Instructions: A Sumerian Agricultural Manual. Aula Orientalis Supplementa 5. Barcelona: Editorial Ausa.

Cimok, F., 2008. The Hittites and Hattusa. Istanbul: A Turizm Yayınları.

Cohen, M. E., 1993. The Cultic Calendars of the Ancient Near East. Bethesda, MD: CDL Press.

Cohen, M. E., 2015. Festivals and Calendars of the Ancient Near East. Bethesda, MD: CDL Press.

Collins, B. J., 2007. The Hittites and their World. Atlanta, GA: SBL Press.

Collins, B. J., forthcoming. "Lost and Found in Translation: Religious Encounters in Hittite Anatolia". In The Oxford Handbook of Religions in the Ancient Near East, edited by T. L. Holm. Oxford: Oxford University Press.

Cornelius, F., 1973. Geschichte der Hethiter. Darmstadt: Wissenschaftliche Buchgesellschaft.

D'Agostino, A., V. Orsi and G. Torri, eds., 2015. Sacred Landscapes of the Hittites and the Luwians. Firenze: Firenze University Press. https://doi.org/10.36253/978-88-6655-904-7

Del Monte, G. F., 1987. "II mese hittita". In Studi di historia e di filologia anatolica dedicati à Giovanni Pugliese Carratelli, edited by F. Imparati. 51-56. Firenze: Elite.

Demirel, S., 2017. "An Essay on Hittite Cultic Calendar Based Upon the Festivals". Athens Journal of History 3 (1): 21-32. https://doi.org/10.30958/ajhis.3-1-2

Duncan, D. E., 1998. Calendar: Humanity's Epic Struggle to Determine a True and Accurate Year. New York: Avon Books.

Edwards, I. E. S., 1993. The Pyramids of Egypt (revised edition). London: Penguin.

Eliade, M., 1954. Cosmos and History: The Myth of the Eternal Return. Princeton, NJ: Princeton University Press.

Eliade, M., 1957. The Sacred and the Profane: The Nature of Religion. New York: Harcourt.

Eliade, M., 1978. A History of Religious Ideas, vol. 1: From the Stone Age to the Eleusinian Mysteries. Chicago: University of Chicago Press.

Erbil, Y. and A. Mouton, 2012. "Water in Ancient Anatolian Religions: An Archaeological and Philological Inquiry on the Hittite Evidence". Journal of Near Eastern Studies 71 (1): 53-74. https://www.jstor.org/ stable/10.1086/664572

Erginer, G., 1984. Uşak Halk Takvimi ve Halk Meteorolojisi. Ankara: Türk Tarih Kurumu Basımevi.

Fowler, C. S. and N. J. Turner, 1999. "Ecological/Cosmological Knowledge and Land Management among Hunter-Gatherers". In The Cambridge Encyclopedia of Hunters and Gatherers, edited by R. B. Lee and R. Daly, 419-427. Cambridge: Cambridge University Press.

Frazer, J. G., 1890. The Golden Bough: A Study in Magic and Religion. London: Macmillan.

Frazer, J. G., 1914. The Golden Bough: A Study in Magic and Religion (Third Edition), Part IV: Adonis, Attis, Osiris, vol. 2. London: Macmillan. 
Gautschy, R., 2020. "Chronologische Grundlagen: Alter Orient und Judentum". In Zeit in den Kulturen des Altertums - Antike Chronologie im Spiegel der Quellen, edited by R. Färber and R. Gautschy, 159-163. Köln: Böhlau. https://doi.org/10.7788/9783412518172.159

Gilan, A., 2019. "Religious Convergence in Hittite Anatolia: The Case of Kizzuwatna". In Religious Convergence in the Ancient Mediterranean, edited by S. Blakely and B. J. Collins, 173-189. Studies in Ancient Mediterranean Religions 2. Atlanta, GA: Lockwood Press. https://doi.org/10.2307/j.ctvd1c9d4.14

Ginzburg, C., 2010. "Mircea Eliade's Ambivalent Legacy". In Hermeneutics, Politics, and the History of Religions: The Contested Legacies of Joachim Wach and Mircea Eliade, edited by C. K. Wedemeyer and W. Doniger, 307-323. Oxford:Oxford University Press. https://doi.org/10.1093/acprof:oso/9780195394337.003.0014

Ginzel, F. K., 1901. "Die astronomischen Kenntnisse der Babylonier und ihre kulturhistorische Bedeutung". Klio 1 (1): 1-25. https://doi.org/10.1524/klio.1901.1.1.189

Ginzel, F. K., 1906. Handbuch der mathematischen und technischen Chronologie - Das Zeitrechnungswesen der Völker. Leipzig: Hinrichs.

Goedegebuure, P., 2008. "Central Anatolian Languages and Language Communities in the Colony Period: A Luwian-Hattian Symbiosis and the Independent Hittites". In Anatolia and the Jazira During the Old Assyrian Period, edited by J. G. Dercksen, 137-180. PIHANS 111. Leiden: Nederlands Instituut voor het Nabije Oosten.

Goetze, A., 1951. "On the Hittite Words for 'Year' and the Seasons and for 'Night' and 'Day'.' Language 27 (4): 467-476. https://doi.org/10.2307/410036

Gonnet, H., 1987. "Tabarna, Favori des Dieux?". Hethitica 8: 177-185.

González-García, A. C. and J. A. Belmonte, 2011. "Thinking Hattusha: Astronomy and Landscape in the Hittite Lands".JournalfortheHistoryofAstronomy42(4):461-494.https://doi.org/10.1177/002182861 104200404

González-García, A. C. and J. A. Belmonte, 2014. "Astronomy and Landscape in Late Bronze Age Central Anatolia". In Proceedings of the Eighth International Congress of Hittitology, Warsaw 5-9 September 2011, edited by P. Taracha, 317-330. Warsaw: Agade.

González-García, A. C. and J. A. Belmonte, 2015. "Orientation of Hittite Monuments". In Handbook of Archaeoastronomy and Ethnoastronomy, edited by C. L. N. Ruggles, 1783-1792. New York: Springer. https://doi. org/10.1007/978-1-4614-6141-8_182

Görke, S., 2019. "Mythological Passages in Hittite Rituals". In Religious Convergence in the Ancient Mediterranean, edited by S. Blakely and B. J. Collins, 163-171. Studies in Ancient Mediterranean Religions 2. Atlanta, GA: Lockwood Press. https://doi.org/10.2307/j.ctvd1c9d4

Gurney, O. R., 1977. Some Aspects of Hittite Religion. Oxford: Oxford University Press.

Güterbock, H. G., 1950. “Hittite Religion”. In Forgotten Religions, edited by V. Ferm, 81-109. New York: Philosophical Library.

Güterbock, H. G., 1958. "The Composition of Hittite Prayers to the Sun". Journal of the American Oriental Society 78: 237-245. https://doi.org/10.2307/595787

Güterbock, H. G., 1964. "Religion und Kultus der Hethiter". In Neuere Hethiterforschung, edited by G. Walser, 4-73. Historia - Zeitschrift für Alte Geschichte; Einzelschriften 7. Wiesbaden: Franz Steiner.

Güterbock, H. G., 1965. "A Votive Sword with Old Assyrian Inscription". In Studies in Honor of Benno Landsberger on his Seventy-Fifth Birthday, edited by H. G. Güterbock and T. Jacobsen, 197-198. Chicago: University of Chicago Oriental Institute.

Güterbock, H. G., 1967. "The Hittite Conquest of Cyprus Reconsidered". Journal of Near Eastern Studies 26: 73-81. https://doi.org/10.1086/371892

Güterbock, H. G.,1975a. "Die Inschriften". In Das hethitische Felsheiligtum Yazılıkaya, edited by K. Bittel, 167187. Berlin: Mann.

Güterbock, H. G., 1975b. “Einschlägige Textstellen”. In Das hethitische Felsheiligtum Yazılıkaya, edited by K. Bittel, 189-192. Berlin: Mann.

Güterbock, H. G., 1988. "Bilingual Moon Omens from Boğasköy”. In A Scientific Humanist: Studies in Memory of Abraham Sachs, edited by E. Leichty, M. dej Ellis and P. Gerardi, 161-173. Philadelphia: The University Museum. 
Güterbock, H. G., 1997. "Some Aspect of Hittite Festivals". In Perspectives on Hittite Civilization: Selected Writings of Hans Gustav Güterbock, edited by H. A. Hoffner, 87-90. Assyriological Studies 26. Chicago: Oriental Institute of the University of Chicago.

Haas, V. 1994. Geschichte der Hethitischen Religion. Handbook of Oriental Studies 1, The Near and Middle East 15. Leiden: Brill. https://doi.org/10.1163/9789004293946

Haas, V. 2002. "Die hethitische Religion". In Die Hethiter und ihr Reich - Das Volk der 1000 Götter, edited by H. Willinghöfer, 102-111. Stuttgart: Theiss.

Haas, V. 2011. "Die Hethiter". In Religionen des Alten Orients, vol. 1: Hethiter und Iran. Göttingen: Vandenhoeck \& Ruprecht.

Hawkins, J. D., 1998. "Hattusa: Home to the Thousand Gods of Hatti". In Capital Cities: Urban Planning and Spiritual Dimensions, edited by J. G. Westenholz, 65-82. Jerusalem: Bible Lands Museum.

Hazenbos, J., 2003. The Organization of the Anatolian Local Cults During the Thirteenth Century B.C.: An Appraisal of the Hittite Cult Inventories. Cuneiform Monographs 21. Leiden: Brill.

Herbordt, S., D. Bawanypeck and J. D. Hawkins, 2011. Die Siegel der Grosskönige und Grossköniginnen auf Tonbullen aus dem Nişantepe-Archiv in Hattusa. Boğazköy-Hattuša 23. Mainz: Zabern.

Hoffner, H. A., 1990. Hittite Myths. Atlanta, GA: Scholar Press.

Hoffner, H. A., 2006. "The Royal Cult in Hatti". In Text, Artefact and Image: Revealing Ancient Israelite Religion, edited by G. Beckman and T. J. Lewis, 132-151. Brown Judaic Studies 346. Providence, RI: Brown Judaic Studies.

Horowitz, W., 2015. "Mesopotamian Star Lists". In Handbook of Archaeoastronomy and Ethnoastronomy, edited by C. L. N. Ruggles, 1829-1833. New York: Springer. https://doi.org/10.1007/978-1-4614-6141-8_187

Huber, P. J. and A. Sachs, 1982. Astronomical Dating of Babylon I and Ur III. Occasional Papers on the Near East 1 (4). Malibu, CA: Undena Publications.

Hunger, H., 2014. Astronomical Diaries and Related Texts from Babylonia, vol. 7: Almanacs and Normal Star Almanacs. Vienna: Verlag der Österreichischen Akademie der Wissenschaften. https://doi.org/10.2307/j. ctt1vw0qhd

Hutter, M., 1997. "Religion in Hittite Anatolia: Some Comments on Volkert Haas: Geschichte der hethitischen Religion". Numen 44 (1): 74-90. https://doi.org/10.1163/1568527972629911

Jeremias, A., 1909. Das Alter der babylonischen Astronomie. Leipzig: Hinrichs.

Jeremias, A., 1929. Handbuch der altorientalischen Geisteskultur. Berlin: De Gruyter. https://doi. org/10.1515/9783111665825

Jones, A., 2004. "A Study of Babylonian Observations of Planets Near Normal Stars". Archive for History of Exact Sciences 58: 475-536. https://doi.org/10.1007/s00407-004-0082-9

Kassian A. S. and I. S. Yakubovich, 2004. "DUTUAŚ in Hittite Texts". In Šarnikzel. Hethitologische Studien zum Gedenken an Emil Orgetorix Forrer, edited by D. Groddek and S. Rößle, 395-407. Dresdner Beiträge zur Hethitologie 10. Dresden: Verlag der Technischen Universität Dresden.

Klinger, J., 1996. Untersuchungen zur Rekonstruktion der hattischen Kultschicht. Wiesbaden: Harrassowitz.

Koch-Westenholz, U., 1993. "Mesopotamian Astrology at Hattusas". In Die Rolle der Astronomie in den Kulturen Mesopotamiens: Beiträge zum 3. Grazer Morgenländischen Symposion (23.-27. September 1991), edited by H. D. Galter, 231-246. Grazer Morgenländische Studien 3. Graz: GrazKult.

Krupp, E. C., 1983. Echoes of the Ancient Skies: The Astronomy of Lost Civilizations. Oxford: Oxford University Press.

Krupp, E. C., 1984. Archaeoastronomy and the Roots of Science. Boulder, CO: Westview Press. https://doi. org/10.4324/9780429049224

Krupp, E. C., 1988. "Light in the lemples". In Records in Stone, edited by C. L. N. Ruggles, 473-499. Cambridge: Cambridge University Press.

Krupp, E. C., 1997a. "Climbing the Cosmic Axis". Griffith Observer 61 (1): 1-8, 21, 24.

Krupp, E. C., 1997b. Skywatchers, Shamans, \& Kings - Astronomy and the Archaeology of Power. New York: John Wiley.

Krupp, E. C., 2000. "Sacred Sex in the Hittite Temple of Yazllıkaya". Archaeology Odyssey 2000 (March/April): 42-51 and 61. 
Krupp, E. C., 2005. "Bedroom Politics and Celestial Sovereignty". In Current Studies in Archaeoastronomy: Conversations Across Time and Space, edited by J. W. Fountain and R. M. Sinclair, 413-429. Durham, NC: Carolina Academic Press.

Krupp, E. C., 2006. "Archaeoastronomy Unplugged: Eliminating the Fuzz Tone from Rock Art Astronomy". In International Rock Art Congress 1994, vol. 3, edited by P. Whitehead, 353-369. American Indian Rock Art 21. Phoenix, AZ: American Rock Art Research Association.

Krupp, E. C., 2015. "Astronomy and Power". In Handbook of Archaeoastronomy and Ethnoastronomy, edited by C. L. N. Ruggles, 67-91. New York: Springer Science+Business Media.

Laroche, E. 1952. "Le Panteon de Yazilikaya". Journal of Cuneiform Studies 6 (3): 115-123. https://doi. org/10.2307/1359082

Laroche, E., 1969. "Les dieux de Yazlıkaya". Révue Hittite et Asianique 27: 61-109.

Lipiński, E., 1986. "Fertility Cult in Ancient Ugarit". In Archaeology and Fertility Cult in the Ancient Mediterranean: Papers Presented at the First International Conference on Archaeology of the Ancient Mediterranean, the University of Malta 2-5 September 1985, edited by A, Bonanno, 207-216. Amsterdam: Grüner.

Macqueen, J. G., 1986. The Hittites and their Contemporaries in Asia Minor. London: Thames and Hudson.

Magli, G. and J. A. Belmonte, 2009. "Pyramids and Stars, Facts, Conjectures and Starry Tales". In In Search of Cosmic Order: Selected Essays on Egyptian Archaeoastronomy, edited by J. A. Belmonte and M. Shaltout, 305-322. Cairo: Supreme Council of Antiquities Press.

Maier, B., 2018. Die Ordnung des Himmels - Eine Geschichte der Religionen von der Steinzeit bis heute. München: C. H. Beck. https://doi.org/10.17104/9783406720130

Masson, E., 1989. Les douze dieux de l'immortalité: croyances indo-européennes à Yazılıkaya. Paris: Les Belles Lettres.

Matos Moctezuma, E., 2003. "Aztec History and Cosmovision". In Moctezuma's Mexico: Visions of the Aztec World, edited by D. Carrasco and E. M. Moctezuma, 3-97, Boulder, CO: University Press of Colorado.

McMahon, G., 1995. "Theology, Priests, and Worship in Hittite Anatolia". In Civilizations of the Ancient Near East, vol. 3, edited by J. M. Sasson and J. Baines, 1981-1995. New York: Simon \& Schuster.

Morley, I., 2010. "Conceptualising Quantification before Settlement: Activities and Issues Underlying the Conception and Use of Measurement". In The Archaeology of Measurement: Comprehending Heaven, Earth and Time in Ancient Societies, edited by I. Morley and C. Renfrew, 7-18. Cambridge: Cambridge University Press. https://doi.org/10.1017/cbo9780511760822.004

Müller-Karpe, A., 2013. “Einige archäologische sowie archäoastronomische Aspekte hethitischer Sakralbauten". In Tempel im Alten Orient, edited by K. Kaniuth, A. Löhnert, J. L. Miller, A. Otto, M. Roaf and W. Sallaberger, 335-353. Colloquium der Deutschen Orient-Gesellschaft 7. Wiesbaden: Harassowitz.

Müller-Karpe, A., 2015. "Planning a Sacred Landscape: Examples from Sarissa and Hattusa". In Sacred Landscapes of the Hittites and the Luwians, edited by A. D'Agostino, V. Orsi and G. Torri, 83-92. Florence: Firenze University Press.

Müller-Karpe, A., 2017. Sarissa - Die Wiederentdeckung einer hethitischen Königsstadt. Darmstadt: Philipp von Zabern.

Naumann, R., 1975. “Die Bauanlagen”. In Das hethitische Felsheiligtum Yazılıkaya, edited by K. Bittel, 91-119. Berlin: Mann.

Ôhashi, Y., 2015. "Astronomy of the Vedic Age". In Handbook of Archaeoastronomy and Ethnoastronomy, edited by C. L. N. Ruggles, 1949-1958. New York: Springer. https://doi.org/10.1007/978-1-4614-6141-8_182

Otten, H., 1963. "Neue Quellen zum Ausklang des hethitischen Reiches". Mitteilungen der Deutschen OrientGesellschaft 84: 1-23.

Otten, H., 1967. "Zur Datierung und Bedeutung des Felsheiligtums von Yazılıkaya. Eine Entgegnung". Zeitschrift für Assyriologie und Vorderasiatische Archäologie 58: 222-240. https://doi.org/10.1515/ zava.1967.58.1.222

Otten, H., 1975. Puduhepa. Eine hethitische Königin in ihren Textzeugnissen. Abhandlungen der geistes- und sozialwissenschaftlichen Klasse 1975, 1. Mainz: Akademie der Wissenschaften und der Literatur. 
Pizzimenti, S., 2013. "The Other Face of the Moon: Some Hints on the Visual Representation of the Moon on Third-Millennium B.C.E. Mesopotamian Glyptic". In Time and History in the Ancient Near East - Proceedings of the $56^{\text {th }}$ Rencontre Assyriologique Internationale at Barcelona 26-30 July 2010, edited by L. Feliu, 265-272. Winona Lake, IN: Eisenbrauns. https://doi.org/10.1515/9781575068565-025

Quack, J. F., 2018. "Astronomy in Ancient Egypt". In The Oxford Handbook of Science and Medicine in the Classical World, edited by P. T. Keyser, 61-70. Oxford: Oxford University Press. https://doi.org/10.1093/oxford$\mathrm{hb} / 9780199734146.013 .64$

Rieken, E., 2019. "Hittite Prayers and Their Mesopotamian Models". In Religious Convergence in the Ancient Mediterranean, edited by S. Blakely and B. J. Collins, 149-162. Studies in Ancient Mediterranean Religions 2. Atlanta, GA: Lockwood Press. https://doi.org/10.2307/j.ctvd1c9d4.12

Riemschneider, K. K., 2004. Die akkadischen und hethitischen Omentexte aus Bogazköy. Dresden: Verlag der Technischen Universität Dresden.

Rochberg, F., 1992. "Calendars (Ancient Near East)". In Anchor Bible Dictionary, edited by D. N. Freedman, 810-814. New York: Doubleday.

Rochberg, F., 2016. Before Nature: Cuneiform Knowledge and the History of Science. Chicago: University of Chicago Press. https://doi.org/10.7208/chicago/9780226406275.001.0001

Rochberg, F., 2018. "Astral Science of Ancient Mesopotamia". In The Oxford Handbook of Science and Medicine in the Classical World, edited by P. T. Keyser, 25-34. Oxford: Oxford University Press. https://doi. org/10.1093/oxfordhb/9780199734146.013.62

Ruggles, C. L. N., ed. 2015. Handbook of Archaeoastronomy and Ethnoastronomy. New York: Springer. https:// doi.org/10.1007/978-1-4614-6141-8

Schachner, A., 2011. Hattuscha - Auf der Suche nach dem sagenhaften Großreich der Hethiter. Munich: C. H. Beck. https://doi.org/10.17104/9783406622847-1

Schmidt, K., 2006. Sie bauten die ersten Tempel - Das rätselhafte Heiligtum der Steinzeitjäger. Munich: C. H. Beck.

Seeher, J., 2011. Gods Carved in Stone - The Hittite Rock Sanctuary of Yazılıkaya. Istanbul: Ege Yayınları.

Seeher, J., 2020. Hattusha Guide - A Day in the Hittite Capital. Istanbul: Ege Yayınları.

Selz, G. J., 2005. Sumerer und Akkader. Munich: C. H. Beck.

Sims, L., 2009: “Entering, and Returning from, the Underworld: Reconstituting Silbury Hill by Combining a Quantified Landscape Phenomenology with Archaeoastronomy". Journal of the Royal Anthropological Institute 15 (2): 386-408. https://doi.org/10.1111/j.1467-9655.2009.01559.x

Sims, L., 2015. “30b - The West Kennet Avenue Stone that Never Was: Interpretation by Multidisciplinary Triangulation and Emergence through Four Field Archaeology". In Skycapes - The Role and Importance of the Sky in Archaeology, edited by F. Silva and N. Campion, 42-57. Oxford: Oxbow Books. https://doi. org/10.2307/j.ctvh1dksg.9

Sipahi T. T., 2019. "Hititlerde Dans-Müzik ve Günümüze Yansımaları", Güzel Sanatlar Fakültesi Dergisi 1 (1): 71-97.

Smith, J. Z. 2005: "Introduction to the 2005 Edition". In The Myth of the Eternal Return: Cosmos and History, by M. Eliade. Princeton, NJ: Princeton University Press.

Spence, K., 2000. "Ancient Egyptian Chronology and the Astronomical Orientation of Pyramids". Nature 408: 320-324. https://doi.org/10.1038/35042510

Spence, K., 2010. "Establishing Direction in Early Egyptian Burials and Monumental Architecture: Measurement and the Spatial Link with the 'Other'". In The Archaeology of Measurement: Comprehending Heaven, Earth and Time in Ancient Societies, edited by I. Morley and C. Renfrew, 170-180. Cambridge: Cambridge University Press. https://doi.org/10.1017/cbo9780511760822.018

Steele, J. M., 2012. "Living with a Lunar Calendar in Mesopotamia and China". In Living the Lunar Calendar, edited by J. Ben-Dov, W. Horowitz and J. M. Steele, 373-387. Oxford: Oxbow Books. https://doi. org/10.2307/j.ctvh1dj98.22

Steiner, D. T., 2001. Images in Mind: Statues in Archaic and Classical Greek Literature and Thought. Princeton, NJ: Princeton University Press. https://doi.org/10.2307/j.ctv14164b9 
Steitler, C., 2017. The Solar Deities of Bronze Age Anatolia - Studies in Texts of the Early Hittite Kingdom. Studien zu den Boğazköy-Texten 40. Wiesbaden: Harrassowitz.

Stern, S., 2012. Calendars in Antiquity: Empires, States, and Societies. Oxford: Oxford University Press.

Stucken, E., 1896-1907. Astralmythen der Hebraeer, Babylonier und Aegypter. Religionsgeschichtliche Untersuchungen, 5 vols. Leipzig: Pfeiffer.

Süel, A., 1985, Hitit Kaynaklarında Tapınak Görevlileri ile Ilgili Bir Direktif Metni, Ankara: Ankara Üniversitesi, Dil ve Tarih Coğrafya Fakültesi Yayınları.

Thompson, G. D., 2020: "The Development, Heyday, and Demise of Panbabylonism" [online]. Accessed November 2020 http://members.westnet.com.au/gary-david-thompson/page9e.html

Torri, G. and S. Görke, 2013. "Hittite Building Rituals - Interaction between their Ideological Function and Find Spots". In Approaching Rituals in Ancient Culture, edited by C. Ambos and L. Verderame, 287-300. Rivista Degli Studi Orientali 86.2. Pisa: Fabrizio Serra.

Van der Waerden, B. L., 1966. Die Anfänge der Astronomie - Erwachende Wissenschaft, vol. 2. Groningen: Nordhoff.

Van der Waerden, B. L., 1974: Science Awakening, vol. 2: The Birth of Astronomy. Leyden: Noordhoff International Publishing.

Verderame, L., 2015. "Mesopotamian Celestial Divination". In Handbook of Archaeoastronomy and Ethnoastronomy, edited by C. L. N. Ruggles, 1835-1839. New York: Springer. https://doi.org/10.1007/978-14614-6141-8_182

Weidner, E. F., 1923. "Astrologische Texte aus Boghazköi. Ihre sprachliche und kulturhistorische Bedeutung". Archiv für Keilschriftforschung, 1: 1-8.

Weidner, E. F., 1931. “Der Tierkreis und die Wege am Himmel". Archiv für Orientforschung 7: 170-178.

Weinstock, S., 1949. "Lunar Mansions and Early Calendars". Journal of Hellenic Studies 69: 48-69. https://doi. org/10.2307/629462

Wheatley, P.,1971. The Pivot of the Four Quarters: A Preliminary Enquiry into the Origins and Character of the Ancient Chinese City. Edinburgh: University Press.

Winckler, H., 1903. "Himmels- und Weltenbild der Babylonier als Grundlage für die Weltanschauung aller Völker". Der alte Orient 3 (2-3): 37-67.

Winckler, H., 1904. Die Weltanschauung des Alten Orients. Leipzig: Eduard Pfeiffer.

Winckler, H., 1907. Die babylonische Geisteskultur in ihren Beziehungen zur Kulturentwicklung der Menschheit. Leipzig: Quelle \& Meyer.

Woudhuizen, F. C., 2017. “Selected Cuneiform Luwian Texts”. Talanta 48-49: 329-367.

Zangger, E. and R. Gautschy, 2019. “Celestial Aspects of Hittite Religion: An Investigation of the Rock Sanctuary Yazilıkaya". Journal of Skyscape Archaeology 5 (1): 5-38. https://doi.org/10.1558/jsa.37641

Zangger, E. and R. Gautschy, 2020. “The Hittite Rock Sanctuary of Yazılıkaya: A Time-Keeping Device from c. 1230 B.C.." In Harmony and Symmetry: Celestial Regularities Shaping Human Culture, edited by S. Draxler, M. E. Lippitsch and G. Wolfschmidt, 98-106. Hamburg: tredition.

Zólyomi, G., 2010. "Hymns to Ninisina and Nergal on the Tablets Ash 1911.235 and Ni 9672". Your Praise is Sweet: A Memorial Volume for Jeremy Black from Students, Colleagues and Friends, edited by H. D. Baker, E. Robson and G. Zólyomi, 413-428. London: British Institute for the Study of Iraq. 